\title{
Evaluating the influences of biomass burning during 2006 BASE-ASIA: a regional chemical transport modeling
}

\author{
J. S. Fu ${ }^{1}$, N. C. Hsu ${ }^{2}$, Y. Gao ${ }^{1}$, K. Huang ${ }^{1}$, C. Li ${ }^{2,3}$, N.-H. Lin ${ }^{4}$, and S.-C. Tsay ${ }^{2}$ \\ ${ }^{1}$ Department of Civil and Environmental Engineering, University of Tennessee, Knoxville, TN, USA \\ ${ }^{2}$ NASA/Goddard Space Flight Center, Greenbelt, MD, USA \\ ${ }^{3}$ Earth System Science Interdisciplinary Center, University of Maryland, College Park, MD, USA \\ ${ }^{4}$ Department of Atmospheric Sciences, National Central University, Chung-Li, Taiwan
}

Correspondence to: J. S. Fu (jsfu@utk.edu)

Received: 9 September 2011 - Published in Atmos. Chem. Phys. Discuss.: 7 December 2011

Revised: 5 March 2012 - Accepted: 8 April 2012 - Published: 2 May 2012

\begin{abstract}
To evaluate the impact of biomass burning from Southeast Asia to East Asia, this study conducted numerical simulations during NASA's 2006 Biomass-burning Aerosols in South-East Asia: Smoke Impact Assessment (BASE-ASIA). Two typical episode periods (27-28 March and 13-14 April) were examined. Two emission inventories, FLAMBE and GFED, were used in the simulations. The influences during two episodes in the source region (Southeast Asia) contributed to the surface $\mathrm{CO}, \mathrm{O}_{3}$ and $\mathrm{PM}_{2.5}$ concentrations as high as $400 \mathrm{ppbv}, 20 \mathrm{ppbv}$ and $80 \mu \mathrm{g} \mathrm{m}^{-3}$, respectively. The perturbations with and without biomass burning of the above three species during the intense episodes were in the range of 10 to $60 \%, 10$ to $20 \%$ and 30 to $70 \%$, respectively. The impact due to long-range transport could spread over the southeastern parts of East Asia and could reach about 160 to $360 \mathrm{ppbv}, 8$ to $18 \mathrm{ppbv}$ and 8 to $64 \mu \mathrm{g} \mathrm{m}^{-3}$ on $\mathrm{CO}, \mathrm{O}_{3}$ and $\mathrm{PM}_{2.5}$, respectively; the percentage impact could reach 20 to $50 \%$ on $\mathrm{CO}, 10$ to $30 \%$ on $\mathrm{O}_{3}$, and as high as $70 \%$ on $\mathrm{PM}_{2.5}$. In March, the impact of biomass burning mainly concentrated in Southeast Asia and southern China, while in April the impact becomes slightly broader and even could go up to the Yangtze River Delta region.
\end{abstract}

Two cross-sections at $15^{\circ} \mathrm{N}$ and $20^{\circ} \mathrm{N}$ were used to compare the vertical flux of biomass burning. In the source region (Southeast Asia), $\mathrm{CO}, \mathrm{O}_{3}$ and $\mathrm{PM}_{2.5}$ concentrations had a strong upward transport from surface to high altitudes. The eastward transport becomes strong from 2 to $8 \mathrm{~km}$ in the free troposphere. The subsidence process during the long-range transport contributed 60 to $70 \%, 20$ to $50 \%$, and $80 \%$ on $\mathrm{CO}, \mathrm{O}_{3}$ and $\mathrm{PM}_{2.5}$, respectively to surface in the downwind area. The study reveals the significant impact of Southeastern Asia biomass burning on the air quality in both local and downwind areas, particularly during biomass burning episodes. This modeling study might provide constraints of lower limit. An additional study is underway for an active biomass burning year to obtain an upper limit and climate effects.

\section{Introduction}

The aerosols emitted by biomass burning contain a significant fraction of partially oxidized organic carbon and black carbon or soot, which could have significant climatic implications and uncertainty (IPCC, 2007). During the combustion process of biomass, substantial amounts of nitrogen oxides, carbon monoxide, and hydrocarbons are produced, which could be precursors of ozone. A positive link between ozone and smoke aerosol has been identified by satellite observation and modeling (Thompson et al., 2001). Aerosol hygroscopic properties could be changed due to the addition of biomass burning aerosol (Kim et al., 2006; Rissler et al., 2006), which further changes cloud microphysical properties (Guyon et al., 2005) and leads to smaller ice crystals and variations of water vapor budget and distribution in the atmosphere (Kim et al., 2009; Sherwood, 2002). The atmospheric temperature profile is also influenced (Davidi et al., 2009), as is solar irradiation due to the aerosol dimming effect (Winkler et al., 2008). Patra et al. (2005) compared the inversion results with biogeochemical model simulations to provide 
strong evidence that both natural and anthropogenic biomass burning constitute a major component in land-atmosphere carbon flux anomalies. Potter et al. (2001) reported the estimation of carbon losses by biomass burning on the Brazilian Amazonian region from ecosystem modeling and satellite data analysis.

Although biomass burning studies in the last decade have focused on the physical, chemical, and thermodynamic properties of biomass-burning particles (Reid et al., 2005), model simulation results of biomass burning aerosol are still limited. Most of recent model studies focus on Mexico, South America and Africa, like several recent field projects including SAFARI 2000 (Swap et al., 2003), LAB-SMOCC (Chand et al., 2006; Guyon et al., 2005), the Dust and Biomassburning Experiment (Haywood et al., 2008) and African Monsoon Multidisciplinary Analysis (Mari et al., 2008).

Southeast Asia is one of the major biomass-burning emission source regions in the world (Streets et al., 2004). Both biomass and fossil combustion processes are potential sources of the extensive Asian Brown Clouds (ABC) over South Asia (Gustafsson et al., 2009). The smoke plume from biomass burning generally spreads downwind thousands of kilometers away and affects air quality, human health, and regional climate. To date, information on the regional distribution of biomass-burning aerosols from Asia remains limited, and their regional radiative impact is not well understood (Wang et al., 2007).

Early studies showed the springtime high ozone events in the lower troposphere from Southeast Asian biomass burning (Liu et al., 1999). The effects of Southeast Asia biomass burning on aerosols and ozone concentrations over the Pearl River Delta (PRD) region was studied using satellite data, ground measurements, and models; it was suggested that $\mathrm{O}_{3}$ productivity is reduced due to the reduced UV intensity under the influence of Southeast Asia biomass burning (Deng et al., 2008). Choi and Chang (2006) described the use of MOPITT to evaluate the influence of Siberian biomass burning on $\mathrm{CO}$ levels around Korea and Japan. Spatial distributions of black carbon (BC) and organic carbon (OC) aerosols were simulated along with the radiative forcing of the Asian biomass burning (Wang et al., 2007). The influence of biomass burning from Southeast Asia on $\mathrm{CO}, \mathrm{O}_{3}$ and radical $\left(\mathrm{OH}, \mathrm{HO}_{2}\right)$ outflow was also simulated by Tang et al. (2003). A new transport mechanism of biomass burning from Indochina was discovered using the WRF/Chem model (Lin et al., 2009). Despite these efforts, however, comprehensive estimates of the impact of Southeast Asia biomass burning on the downstream regions are still lacking.

This study is part of NASA's BASE-ASIA experiment (Biomass-burning Aerosols in South-East Asia: Smoke Impact Assessment; cf. http://smartlabs.gsfc.nasa.gov/) in 2006. One of the objectives of BASE-ASIA is to investigate the regional impact of biomass burning on Southeast and East Asia. Besides the air quality impact resulting from biomass burning, the biomass burning aerosols could also af- fect radiative forcing. However, large uncertainty exists in coupled climate/air quality models, especially aerosol feedback may not be fully implemented (Zhang, 2008) and in the estimates of emission inventories, this study identifies the influences of biomass burning on East Asia during intense burning episodes by employing a regional "one atmosphere" model, the Community Multiscale Air Quality Modeling System (CMAQ) (Byun and Schere, 2006; Byun and Ching, 1999) in the offline mode. Model simulations were compared with satellite observations and in situ ground measurements to validate the model. Two different biomass burning emission inventories were evaluated. Model simulations were compared with satellite observations and in situ ground measurements to validate the model, including $\mathrm{PM}_{2.5}$, trace gases and aerosol optical depths. The long-range transport and vertical transport patterns of particles and trace gases were illustrated and quantified by conducting scenario simulation of cutting off the biomass burning emission.

\section{Methodology}

\subsection{Model description}

This study uses the Models-3/Community Multiscale Air Quality (CMAQ) modeling system. The model has been widely used to predict atmospheric transport in East Asia (Streets et al., 2007; Carmichael et al., 2008; Chuang et al., 2008; Fu et al., 2008, 2009a, b; Wang et al., 2008, 2010a, b; Xu et al., 2008). CMAQ is configured with 19 layers extending from the surface to the tropopause $(\sim 15 \mathrm{~km})$. The modeling domain covers most of Southeast Asia and part of East Asia with a $27 \times 27 \mathrm{~km}$ grid resolution. A Lambert projection with the two true latitudes of $15^{\circ} \mathrm{N}$ and $40^{\circ} \mathrm{N}$ is used. The center of projection is set at $114^{\circ} \mathrm{E}$ and $28.5^{\circ} \mathrm{N}$. The detailed model configuration is also shown in Table 1. The modeling domain is shown in Fig. 1. The CMAQ is driven by the Weather Research and Forecasting model version 3.1.1 (WRF). To prepare the WRF Preprocessing System (WPS), we used the National Centers for Environmental Prediction (NCEP) Final Analyses dataset (ds083.2) with a resolution of $1.0 \times 1.0$ degree grids for every six hours. The one-way nested approach with four-dimensional data assimilation (FDDA) in WRF was performed from a mother domain with an $81 \times 81 \mathrm{~km}$ horizontal resolution over Asia nested down to $27 \times 27 \mathrm{~km}$. Other WRF configurations are also listed in Table 1. A Meteorology/Chemistry Interface Processor (MCIP) 3.4 was used to process the WRF output; the outcome is an input of CMAQ 4.6. 
Table 1. Model configuration of WRF and CMAQ.

\begin{tabular}{ll}
\hline & \multicolumn{1}{c}{ WRF Configuration } \\
\hline Meteorology model & WRF v3.1.1 \\
Explicit precipitation scheme & WRF single - moment 3 - class scheme \\
Longwave Radiation & RRTM \\
Shortwave Radiation & Dudhia scheme \\
Surface-layer option & MM5 similarity (Monin - Obukhov scheme) \\
Land-surface & Thermal diffusion scheme \\
Advection & Global mass-conserving scheme \\
Planetary boundary layer scheme & YSU \\
Cumulus option & Grell \\
\hline & CMAQ Configuration \\
\hline Chemistry model & CMAQ v4.6 \\
Horizontal resolution & $27 \times 27$ km \\
Vertical resolution & 19 sigma-pressure levels (with the top pressure of 100 mb) \\
Projection & Lambert Conformal Conic \\
Advection & Piecewise parabolic scheme \\
Vertical diffusion & K-theory \\
Gas-phase chemistry & CB05 with Euler Backward Iterative solver (Hertel et al., 1993) \\
Dry deposition & Wesely (1989) \\
Wet deposition & Henry's law \\
Aqueous chemistry & Walcek and Aleksic (1998) \\
Aerosol mechanism & AERO4 \\
\hline
\end{tabular}

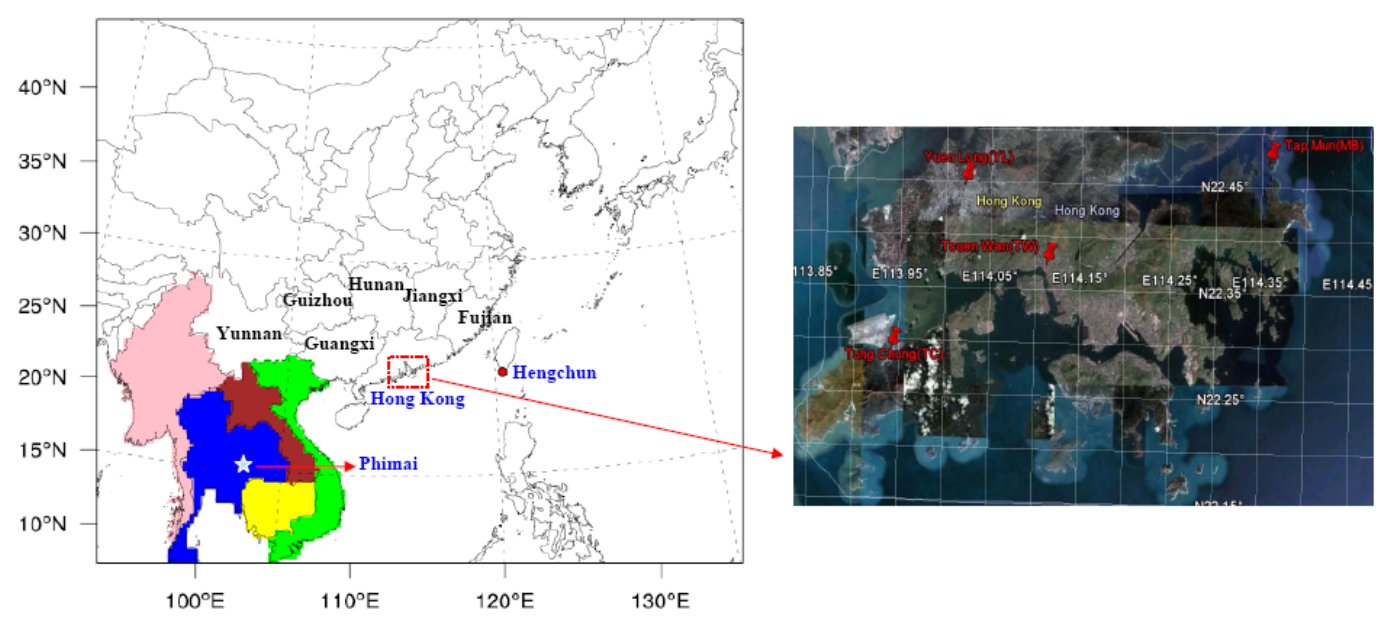

Fig. 1. The $27 \times 27 \mathrm{~km}$ nested domain from the mother domain with a resolution of $81 \times 81 \mathrm{~km}$. Five countries with dominant biomass burning emission in Southeast Asia in this study are colored (Pink: Burma; Bule: Thailand; Yellow: Cambodia; Red: Laos; Green: Vietnam). The observational sites used in this study for model performance are also plotted in the figure, including one site in Thailand (Phimai), four sites in Hong Kong (Tsuen Wan, Yuen Long, Tap Mun and Tung Chung) and one site in Taiwan (Hengchun).

\subsection{Emissions}

\subsubsection{Anthropogenic emissions}

Anthropogenic emissions are based on NASA's 2006 Intercontinental Chemical Transport Experiment-Phase B (INTEX-B) emission inventory (Zhang et al., 2009). The inventory mainly includes gaseous pollutants, such as $\mathrm{CO}_{2}$,
$\mathrm{SO}_{2}, \mathrm{NO}_{\mathrm{x}}, \mathrm{CO}, \mathrm{CH}_{4}$, and $\mathrm{NH}_{3}$; non-methane volatile organic compounds (NMVOC); and particulate pollutants, such as submicron black carbon aerosol (BC), submicron organic carbon aerosol (OC), $\mathrm{PM}_{2.5}$, and $\mathrm{PM}_{10}$. NMVOC can be categorized into 16 subspecies to match the CB05 mechanism used in CMAQ. The main sources of these emissions are industrial, residential, power plants, and transportation. $\mathrm{NH}_{3}$ emissions are mainly from six sub-sectors, including 
cattle, pigs, other animals, fertilizer use, biofuel use, and other sources. The $\mathrm{CH}_{4}$ emissions were derived from rice cultivation, animal emissions, landfill, wastewater treatment, coal mining/combustion, oil/gas extraction and use, and biofuel combustion (Du, 2008).

\subsubsection{Biogenic and biomass burning emissions}

Biogenic isoprene emissions were generated from MEGAN (Model of Emissions of Gases and Aerosols from Nature) to estimate regional and global biogenic emissions. In this study, MEGAN v2.02 was used to generate the hourly biogenic emissions inventories (http://bai.acd.ucar.edu/Megan/ index.shtml).

The joint Navy, NASA, NOAA, and universities Fire Locating and Modeling of Burning Emissions (FLAMBE) project was used to investigate a consistent system of emissions (Reid et al., 2009). Hourly emissions from FLAMBE were taken from the 2006 data (http://www.nrlmry.navy.mil/ aerosol_web/arctas_flambe/data_hourly/). The fire locations and emissions were computed based on the Global Land Cover Characterization Version 2 database (http://edc2.usgs. gov/glcc/glcc.php). This dataset contains hourly biomass burning of areas as well as carbon emissions in a certain location with coordinated latitudes and longitudes.

The Global Fire Emissions Database, Version 2 (GFEDv2.1), another biomass burning emission data source, is derived from MODIS fire count data (van der Werf et al., 2006). This dataset comprises eight-day periods throughout 2006 and monthly average emissions. In this study, carbon emissions from FLAMBE and GFED were both allocated to the simulation domain with a resolution of $27 \times 27 \mathrm{~km}$. Since the temporal resolution of GFED data is eight days, the hourly profile in FLAMBE was used to distribute GFED emissions. Quantitative comparisons between the FLAMBE and GFEDv2.1 biomass emission inventories were conducted in this study before one inventory was selected to further estimate the regional impact of Southeast Asian biomass burning.

Both biomass burning emission inventories estimate carbon emissions, which were then converted to other species. Andreae and Merlet (2001) reported emission factors $(\mathrm{EF})$ for conversion from carbon emissions to other species $\left(\mathrm{CO}, \mathrm{CH}_{4}, \mathrm{NMHC}, \mathrm{NO}_{\mathrm{x}}, \mathrm{NH}_{3}, \mathrm{SO}_{2}, \mathrm{PM}_{2.5}\right.$, TPM, OC and $\mathrm{BC}$ ) in terms of different land use types, such as tropical forest, extratropical forest, agricultural residues, and savanna and grassland. Based on the 24 land use types (http://www.mmm.ucar.edu/wrf/users/docs/ user_guide_V3/users_guide_chap3.htm\#_Land_Use_and) and the WRF Preprocessing System (WPS) output, we categorized the land use types into several groups: EF of the grids with land use category 2, 3, 4 (Dryland Cropland and Pasture, Irrigated Cropland and Pasture, and Mixed Dryland/Irrigated Cropland and Pasture, respectively) were assigned to agricultural residues; EF of the grids with land use category 5, 6,
7, 8, 9, 10 (Cropland/Grassland Mosaic, Cropland/Woodland Mosaic, Grassland, Shrubland, Mixed Shrubland/Grassland, Savanna, respectively) were assigned to savannas and grasslands; EF of the grids with land use category 11, 12, 14, 15 (Deciduous Broadleaf Forest, Deciduous Needleleaf Forest, Evergreen Needleleaf, and Mixed Forest, respectively) were assigned to extratropical forests; and the grids with land use category 13 (Evergreen Broadleaf) were assigned to tropical forests. Grids with other land use types usually do not have biomass burnings (van der Werf et al., 2006).

\subsection{Injection height of biomass burning emission}

Determining the injection height is important for the regional chemical model and could significantly affect long-range transport. Leung et al. (2007) used the GEOS-Chem global model to simulate the transport of boreal forest fire smoke under different scenarios and found different $\mathrm{CO}$ responses for different injection heights. Freitas et al. (2006) used the 1-D plume rise model to simulate the injection height of fire emissions and found that model outputs were more consistent when the injection height of vigorous fire reached mid-troposphere. Hyer et al. (2007) examined the injection height under five different scenarios using the University of Maryland CTM (Allen et al., 1996a, b) and found that pressure-weighted injection through the tropospheric column into the midtroposphere agreed the best with observations. In this study, we adopted the methodology implemented in Sparse Matrix Operator Kernel Emissions (SMOKE) version 2.6 for calculating the plume fractions in different layer heights given a bottom $\left(P_{\text {bot }}\right)$ and top $\left(P_{\text {top }}\right)$ of a plume. The hourly top of the plume was calculated as follows: $P_{\text {tophour }}=$ $\left(\mathrm{BE}_{\mathrm{hour}}\right)^{2} \cdot\left(\mathrm{BE}_{\mathrm{size}}\right)^{2} \cdot P_{\mathrm{top}_{\max }}$, where BE is the buoyant efficiency looked up from the hourly or size class tables. The hourly bottom of plume was similarly calculated as: $P_{\text {bothour }}$ $=\left(\mathrm{BE}_{\text {hour }}\right)^{2} \cdot\left(\mathrm{BE}_{\text {size }}\right)^{2} \cdot P_{\text {bot }_{\text {max }}}$. The look up table of $\mathrm{BE}_{\text {hour }}$ and $\mathrm{BE}_{\text {size }}$ are described by Air Sciences, Inc. (2005).

\section{In-situ and satellite observation}

\subsection{BASE-ASIA field campaign}

During the BASE-ASIA field campaign from February to May 2006, ground-based measurements were conducted at a rural site in Phimai, Thailand. This site was about $260 \mathrm{~km}$ to the northeast of Bangkok, about $8 \mathrm{~km}$ to the southeast of the local township (population $\sim 10000$ ), and surrounded by agricultural land. This rural site was rarely influenced by industrial or mobile sources, but occasional local agricultural fires did occur, particularly in March and April. Several trace gases, aerosol optical and microphysical properties, and meteorological parameters were measured with the NASA/GSFC COMMIT (Chemical, Optical, and Microphysical Measurements of In-situ Troposphere) mobile laboratory. The instrumentation of COMMIT has been discussed 
in detail elsewhere (Li et al., 2010) and is only briefly introduced here. $\mathrm{CO}$ was measured with a modified Thermo Environmental Instruments (Franklin, MA) Model 48C detector (Dickerson and Delany, 1988). A TEI Model 49C was used to monitor $\mathrm{O}_{3}$. Before and after, as well as every 3-4 weeks during the field campaign, the $\mathrm{CO}$ instrument was calibrated with a working standard gas (Scott-Marrin Inc., Riverside, CA) traceable to National Institute of Standards and Technology standard reference materials. The $\mathrm{O}_{3}$ detector was calibrated with an in-house primary standard (TEI Model 49 PS). Aerosol size distribution was determined with an Aerodynamic Particle Sizer spectrometer (APS, TSI Model 3321) and a Scanning Mobility Particle Sizer (SMPS, TSI Model 3081).

\subsection{Observational sites in downwind regions}

The Hengchun observation site in Taiwan is included in the Taiwan Air Quality Monitoring Network (TAQMN) operated by the Environmental Protection Administration. This is a background site located in the most southern part of Taiwan $\left(102.77^{\circ} \mathrm{E}, 21.95^{\circ} \mathrm{N}\right)$ and is an ideal site for the observation of long-range transport of biomass burning from Southeast Asia. Continuous operations of hourly aerosol concentration, trace gases, atmospheric radiation, and meteorological variables are measured at this site. $\mathrm{CO}$ was measured by HORIBA/APMA-360, with a detection limit of $50 \mathrm{ppb} ; \mathrm{O}_{3}$ was measured by ECOTECH/EC9810, with a detection limit of $0.5 \mathrm{ppb}$; and $\mathrm{PM}_{2.5}$ was measured by Thermo/R\&P 1400a with a detection limit of $0.5 \mu \mathrm{g} \mathrm{m}^{-3}$.

Four sites in the Hong Kong Environmental Protection Department (HKEPD) Air Pollution Index (API) network are also used as observational stations for model evaluations. Two of them are Tsuen Wan and Yuen Long on the southwest and northwest of Hong Kong, while the other two are Tap Mun and Tung Chung, which are remote sites located in the northeast of Hong Kong and Lantau Island. $\mathrm{CO}, \mathrm{O}_{3}$, and $\mathrm{PM}_{2.5}$ were continuously measured during the study period. Other detailed information was described elsewhere (Kwok et al., 2010).

\subsection{Satellite observation}

A number of satellite sensors launched in the past decade have proven valuable for studying anthropogenic pollution in the troposphere (Martin, 2008; Richter et al., 2005). In this study, we use the tropospheric $\mathrm{NO}_{2}$ product from the Ozone Monitoring Instrument (OMI) aboard NASA's EOS Aura satellite (for details of the OMI instrument and $\mathrm{NO}_{2}$ product, see Levelt et al., 2006 and Bucsela et al., 2006), and aerosol optical depth (AOD) retrieved from the MODerate Resolution Imaging Spectrometer (MODIS) instrument aboard the Aqua satellite (Krotkov et al., 2008) MODIS provides remotely sensed aerosol information with a resolution of $10 \times 10 \mathrm{~km}$ for this study. Detailed information on
MODIS sensors and global daily observations of aerosols were used to retrieve aerosol properties over land (Remer et al., 2005) and ocean (Tanré et al., 1997). In this study, we use level 2 collection and 5 aerosol optical thickness at $550 \mathrm{~nm}$. Both OMI NO 2 and MODIS AOD products have been widely used in air quality studies to track regional aerosol plumes $(\mathrm{Li}$ et al., 2010a) and characterize power plant emissions ( $\mathrm{Li}$ et al., 2010c).

\section{Results and discussion}

\subsection{Comparison between FLAMBE and GFED emission inventory}

It was necessary to compare the two biomass burning emission, i.e. FLAMBE and GFEDv2, before we performed the model simulation. The total biomass burning emissions in Southeast Asia and East Asia for each month in 2006 are shown in Table 2. In this study, Southeast Asia denoted Burma, Laos, Vietnam, Cambodia, and Thailand as shown in Fig. 1. And East Asia denoted the rest of the model domain. Evidently, Southeast Asia dominated the total carbon emissions in the study domain in both emission inventories, contributing two to three times more biomass burning carbon emissions than East Asia. However, carbon emissions from FLAMBE were 7.58 and 4.86 times that of GFEDv2 for Southeast Asia and East Asia in 2006, respectively. The massive divergences between FLAMBE and GFEDv2 (Reid et al., 2009) were mainly due to the difficulty in estimating the emission inventory from the individual fires. Although the two emission inventories differed in quantity, they show similar seasonal patterns, with March and April as the most active biomass burning periods. The two months contributed $70 \%$ to the total carbon emissions in GFEDv2. The contribution was even higher of $84 \%$ in FLAMBE. Thus, we focus on March and April in this study. Given the 8- to 12-fold difference between the two inventories, we have done simulations with both emission inventories to compare with measurement results in order to select the better inventory. Figure 2 shows the simulation results of carbon monoxide (CO), a typical species or tracer for biomass burning sources by using both emissions, with comparisons to the observation at Phimai. Phimai was chosen as it is located in central Thailand near the biomass burning source regions. The average $\mathrm{CO}$ concentration measured at Phimai was 192.9 ppbv during the study period as shown in Fig. 2. By using two different biomass burning inventories, i.e. FLAMBE and GFED, the correspondingly simulated average CO concentrations were 143.9 and $124.1 \mathrm{ppbv}$, respectively. Although both emission inventories showed underestimation, simulation using FLAMBE was undoubtedly more close to the real atmosphere. As shown in the figure, simulation based on FLAMBE agreed well with the surface measurements and successfully captured the peak values from 27 to 28 March and 13 to 14 
Table 2. The monthly carbon emission (Tg) from GFED and FLAMBE biomass burning emission inventories in both Southeast Asia and outside Southeast Asia in the domain (Referred as East Asia) in 2006, respectively.

\begin{tabular}{|c|c|c|c|c|c|c|c|}
\hline \multirow{2}{*}{$\begin{array}{l}\text { Carbon } \\
\text { Emission }\end{array}$} & \multicolumn{3}{|c|}{ Southeast Asia } & & \multicolumn{3}{|c|}{ East Asia } \\
\hline & GFED $^{1}$ & FLAMBE $^{1}$ & FLAMBE/GFED ${ }^{2}$ & & GFED $^{1}$ & FLAMBE $^{1}$ & FLAMBE/GFED $^{2}$ \\
\hline Jan & 5.54 & 14.01 & 2.53 & & 0.4 & 4.97 & 12.39 \\
\hline Feb & 8.06 & 35.79 & 4.44 & & 1.16 & 10.13 & 8.73 \\
\hline Mar & 28 & 220.9 & 7.89 & & 18.24 & 84.79 & 4.65 \\
\hline Apr & 13.43 & 156.22 & 11.63 & & 1.58 & 21.13 & 13.39 \\
\hline May & 0.9 & 8.74 & 9.7 & & 1.78 & 6.08 & 3.42 \\
\hline Jun & 0.21 & 1.39 & 6.72 & & 1.24 & 1.25 & 1.01 \\
\hline Jul & 0.03 & 0.12 & 3.81 & & 0.94 & 0.66 & 0.7 \\
\hline Aug & 0.02 & 0.08 & 3.54 & & 1.36 & 1.09 & 0.8 \\
\hline Sep & 0.1 & 0.23 & 2.3 & & 0.44 & 0.92 & 2.09 \\
\hline Oct & 0.12 & 0.47 & 4.02 & & 0.73 & 2.21 & 3.02 \\
\hline Nov & 0.55 & 1.92 & 3.47 & & 0.59 & 3.31 & 5.65 \\
\hline Dec & 2.08 & 7.6 & 3.66 & & 0.33 & 3.27 & 9.97 \\
\hline Total & 59.04 & 447.47 & & 7.58 & 28.79 & 139.81 & 4.86 \\
\hline
\end{tabular}

${ }^{1}$ The monthly carbon emission of GFED and FLAMBE are in units of Tg.

2 The ratio of FLAMBE versus GFED (unitless).

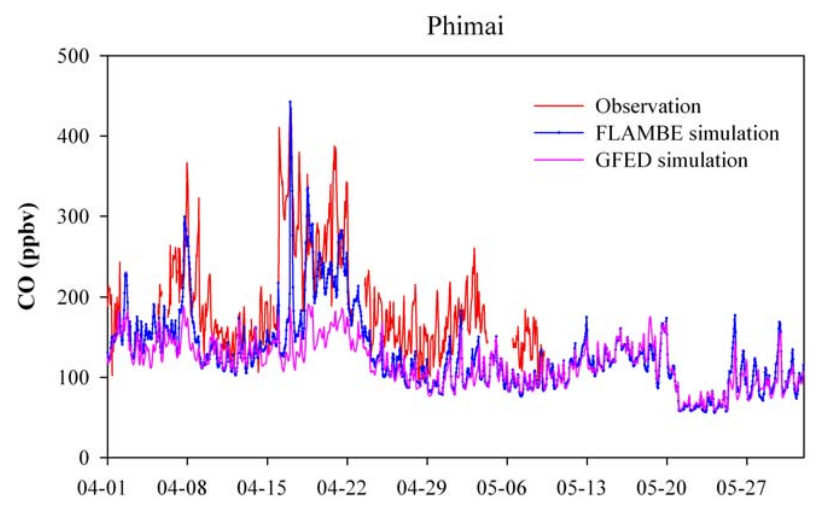

Fig. 2. Model Performance of the temporal CO concentrations with two different biomass burning emission inventories during 1 April to 31 May 2006 at Phimai, Thailand. The red line represents the observation data, and the blue and purple lines represent the modeled CO concentration by using the FLAMBE and GFEDv2.1 biomass burning emissions, respectively.

April. While the simulation based on GFED emissions obviously underestimated the $\mathrm{CO}$ concentrations during the peak periods by as much as 200 to 300 ppbv. This comparison indicated that the FLAMBE emission provided a better representation of biomass burning sources in our model than did the GFED emission. Nam et al. (2010) also found underestimation of $\mathrm{CO}$ emissions at lower subtropical latitudes over Asia using the GFED emissions. Thus, in the further discussion, we use the FLAMBE emission for sensitivity tests and analysis of the large-scale impact of biomass burning in Southeast Asia.

\subsection{Model results and comparison with measurements}

\subsubsection{Comparison of simulations with site measurements}

Figure 3 shows the model performance at ground-based sites in Taiwan and Hong Kong. Time-series of hourly $\mathrm{CO}, \mathrm{O}_{3}$, and $\mathrm{PM}_{2.5}$ concentrations were evaluated. As shown in the figure, the model successfully captured the temporal variation at all sites during the whole study period, indicating relatively good model performance at the downwind sites. Some statistical parameters were used for model evaluations, including MNB (Mean Normalized Bias), MNE (Mean Normalized Gross Error), MFB (Mean Fractional Bias) and MFE (Mean Fractional Gross Error), IOA (Index of Agreement), and Factor 2 analysis (see Appendix A). Table 3 calculates those statistical parameters for $\mathrm{O}_{3}, \mathrm{CO}$, and $\mathrm{PM}_{2.5}$. For $\mathrm{CO}$ at Hong Kong, MNB, MNE, MFB, and MFE were -0.18, 0.35, -0.28 , and 0.40 , respectively, indicating a slight underestimation. While at Taiwan, the statistics showed a moderate overestimation. $\mathrm{O}_{3}$ at all sites showed relatively good performance, as most of the parameters were within or close to the benchmark according to (USEPA, 2007). As for $\mathrm{PM}_{2.5}$, better model performance was found for Hong Kong while it was moderately good for Taiwan. For $\mathrm{CO}, \mathrm{O}_{3}$, and $\mathrm{PM}_{2.5}$, IOA were all higher than 0.6 , indicating reliable model performance. Factor 2 analysis indicated that model values of $\mathrm{CO}$ and $\mathrm{O}_{3}$ had over $60 \%$ fraction lie between 0.5 to 2.0 fold of the measurement data. For $\mathrm{PM}_{2.5}$, the Factor 2 analysis showed lower values, indicating PM were more difficult to predict compared to gaseous species. In addition, we performed comparison between modeled AOD and AERONET measured AOD at four sites. Two of them are 
Table 3. Statistical parameters for model evaluation of $\mathrm{CO}, \mathrm{O}_{3}$, and $\mathrm{PM}_{2.5}$ in Hong Kong and Taiwan, and AOD at four AERONET sites. Definitions of all parameters are described in Appendix A.

\begin{tabular}{|c|c|c|c|c|c|c|c|c|c|c|c|c|}
\hline \multirow[b]{2}{*}{$\mathrm{CO}$} & \multicolumn{4}{|c|}{ Hong Kong } & \multicolumn{4}{|c|}{ Taiwan } & \multicolumn{4}{|c|}{ AERONET } \\
\hline & $\mathrm{O}_{3}-40^{1}$ & $\mathrm{O}_{3}-60^{2}$ & $\mathrm{PM}_{2.5}$ & $\mathrm{CO}$ & $\mathrm{O}_{3-40^{1}}$ & $\mathrm{O}_{3-} 60^{2}$ & $\mathrm{PM}_{2.5}$ & Phimai & Mukdahan & HK_Poly & TW & Kung \\
\hline $\mathrm{No}^{3}$ & 6346 & 404 & 50 & 8733 & 2180 & 1268 & 179 & 2148 & 64 & 70 & 26 & 80 \\
\hline MNB & -0.18 & 0.02 & -0.09 & 0.02 & 0.41 & 0.23 & -0.03 & -0.09 & -0.39 & -0.31 & 0.58 & 0.60 \\
\hline MNE & 0.35 & 0.29 & 0.23 & 0.55 & 0.59 & 0.39 & 0.37 & 0.79 & 0.46 & 0.39 & 0.74 & 0.76 \\
\hline MFB & -0.28 & -0.05 & -0.15 & -0.22 & 0.19 & 0.13 & -0.14 & -0.55 & -0.61 & -0.48 & 0.31 & 0.31 \\
\hline MFE & 0.40 & 0.31 & 0.27 & 0.57 & 0.41 & 0.33 & 0.38 & 0.86 & 0.67 & 0.55 & 0.50 & 0.53 \\
\hline $\mathrm{IOA}^{4}$ & 0.63 & 0.89 & 0.84 & 0.73 & 0.70 & 0.76 & 0.86 & 0.66 & 0.64 & 0.48 & 0.60 & 0.58 \\
\hline $\mathrm{F} 2^{5}$ & 0.69 & 0.83 & 0.64 & 0.59 & 0.82 & 0.98 & 0.91 & 0.43 & 0.56 & 0.61 & 0.69 & 0.70 \\
\hline
\end{tabular}

1 A cutoff value of $40 \mathrm{ppbv}$ is set.

2 A cutoff value of $60 \mathrm{ppbv}$ is set.

3 Number of the observation data available for model evaluation.

${ }^{4}$ Index of aggrement, see Apprendix A for definition.

${ }^{5}$ Factor 2, see Apprendix A for definition.
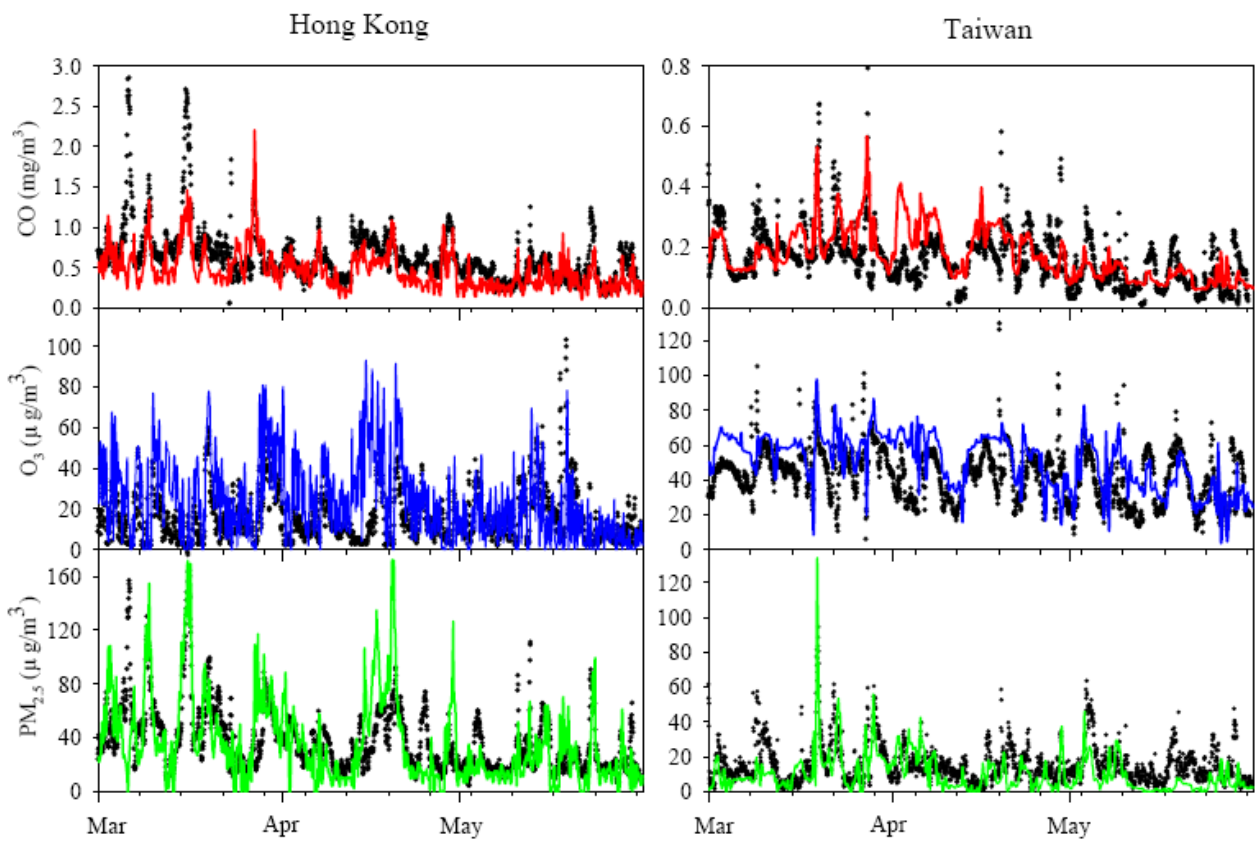

Fig. 3. Time-series of the hourly modeled species concentrations (color lines) and observations (black dots) for $\mathrm{CO}, \mathrm{O}_{3}$, and $\mathrm{PM}_{2.5}$ in $\mathrm{Hong}$ Kong and Taiwan, respectively. The study period covered March, April, and May in 2006. The modeled and observational results in Hong Kong were averaged from 4 monitoring sites, i.e. Tsuen Wan, Yuen Long, Tap Mun and Tung Chung.

located in Thailand (i.e. Phimai and Mukdahan), and the other two are located in Hong Kong (HK_Poly) and Taiwan (TW_ChengKung), respectively. At the two sites of Thailand, AOD were underestimated. Lower local anthropogenic emissions or biomass burning emission were probably responsible for this. Model over-predicted AOD at downwind regions. IOA analysis shows moderate model performance at Mukdahan and relatively good performances at other sites. Factor 2 analysis shows that most of the simulated results lie in the vicinity of observational data. Overall, the CMAQ model could simulate reasonably well as compared to the observational datasets. As illustrated from the temporal pattern in Fig. 3, most episodic peaks occurred during March and April, while less in May. This was consistent with the monthly biomass burning emission as discussed in Sect. 4.1. In the further discussions, we tended to pick up some intensive episodes based on the daily carbon emission rate and the temporal variation pattern in both the source region (Phimai) and downwind regions (Taiwan and Hong Kong). Here, two 

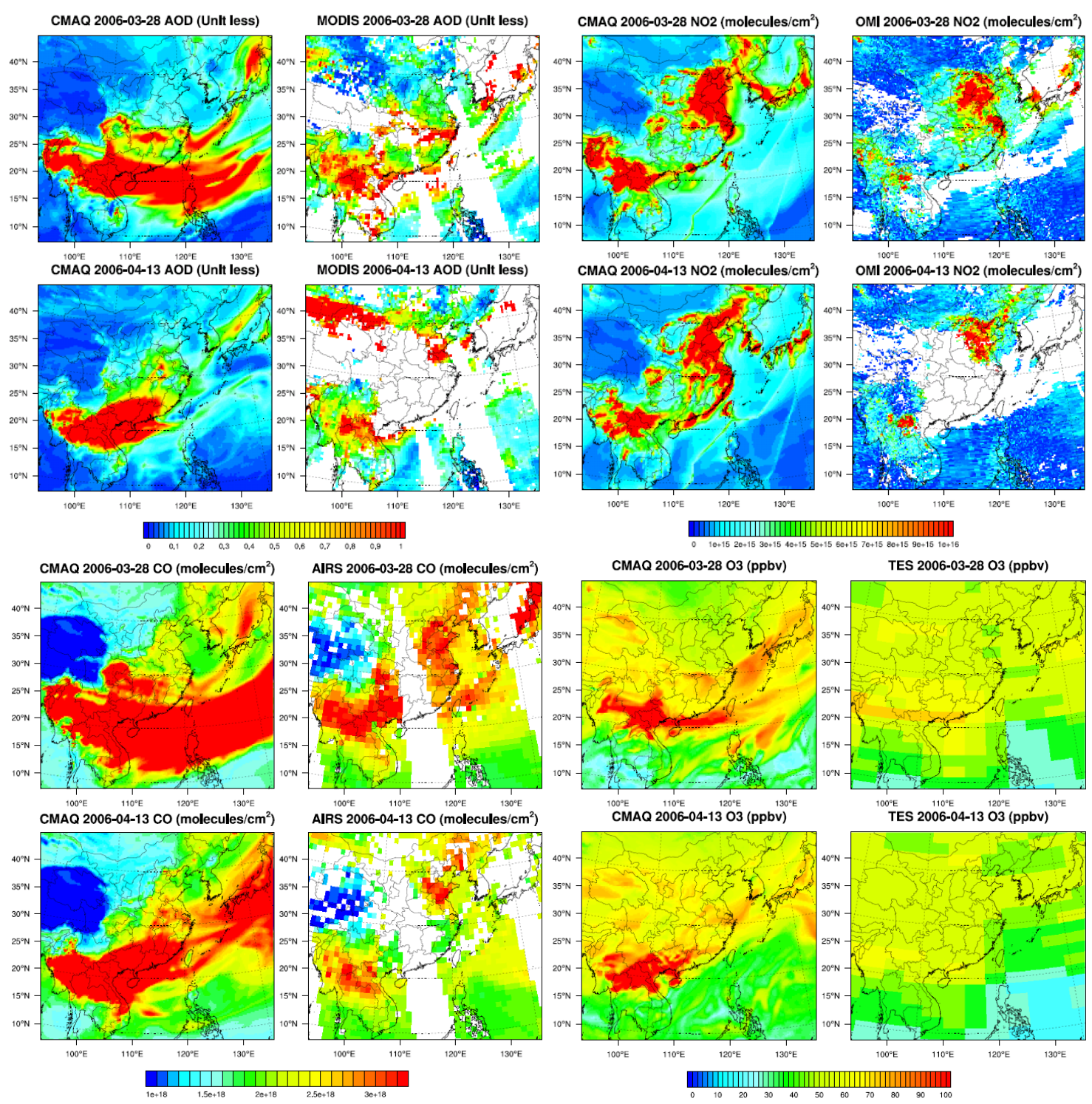

Fig. 4. Comparison between model simulated results and satellite products on 28 March and 13 April 2006, respectively. The evaluated satellite products include AOD, column $\mathrm{NO}_{2}$ and $\mathrm{CO}$ concentration (molecules $\mathrm{cm}^{-2}$ ) and $\mathrm{O}_{3}$ concentration (ppbv) at around $820 \mathrm{hPa}$. AOD was retrieved from the composite Aqua/MODIS C005 using the Deep Blue algorithm at $550 \mathrm{~nm}$ and gridded to $0.5 \times 0.5^{\circ}$ resolution. Column $\mathrm{NO}_{2}$ concentration was retrieved from Ozone Monitoring Instrument (OMI) aboard NASA's EOS Aura satellite. Column CO concentration was retrieved from the Atmospheric Infrared Sounder (AIRS), and $\mathrm{O}_{3}$ concentrations was retrieved from the Tropospheric Emission Spectrometer (TES).

intensive episodes were chosen, i.e. 27-28 March and 13-14 April.

\subsubsection{Remote sensing observations}

Besides the model evaluation from ground-based observation, we also evaluated the regional consistence between model results and remote sensing map during the two intensive biomass burning episodes as stated above. Figure 4 compares the regional distribution of the observed satellite parameters with the simulated results, including Aerosol Op- tical Depth (AOD), column $\mathrm{NO}_{2}$ concentration, column $\mathrm{CO}$ concentration and $\mathrm{O}_{3}$ concentration at around $820 \mathrm{hPa}$. Gaps in satellite data were mainly due to possible cloud interference and limited satellite swath. The satellite observations on 28 March and 13 April were selected to evaluate the model performance here.

As shown in the Fig. 4, the satellite observation and model output demonstrated a similar spatial pattern. During both episodes, hot spots were observed and moderately well simulated in the Southeast Asia region. The simulated AOD 
was converted by multiplying the aerosol chemical species in the CMAQ model with the aerosol extinction coefficients and then integrated with all altitudes. The detailed method was described in Appendix B. The model generally captured the observed magnitude and distribution of MODIS AOD in Fig. 4. The gaps in satellite AOD were mainly due to cloudy scenes and sun glint over the ocean. Both satellite and CMAQ model showed heavy aerosol loading over the biomass burning region in Southeast Asia and in the downwind areas, suggesting strong biomass burning activities and long-range transport. On 28 March, two main high AOD regions were observed and simulated, one in Southeast Asia, which covered large areas extending eastward to the Western Pacific, and the other in a relatively small area located between $25^{\circ} \mathrm{N}$ and $30^{\circ} \mathrm{N}$ near the Yangtze River Region. As for the second episode (13 April), although no enough satellite data was available in downwind areas, the model still simulated a large scale transport of aerosol. However, the level of the long-range transport during the second episode was not as strong as the first one. On 13 April, the model seemed to predict lower AOD values in the northern part of China than the MODIS observation (Fig. 4). This underestimation was probably due to the lack of a dust module in CMAQ, as dust events derived from the Gobi desert in Northern China occurred during this period (Huang et al., 2010; Zhang et al., 2010).

There were two enhancement regions of $\mathrm{NO}_{2}$, one in the Southeast Asia region and the other in the industrialized eastern part of mainland China. Although the nitrogen oxides were not the main species emitted from biomass burning, high column concentrations of $\mathrm{NO}_{2}$ were still present over most of Southeast Asia in both the remote sensing data and model simulation. The areas of high column $\mathrm{NO}_{2}$ were confined to the source regions in Southeast and East Asia (Fig. 4), suggesting negligible long-range transport of the relatively short-lived $\mathrm{NO}_{2}$ and different sources of $\mathrm{NO}_{2}$ in the two regions. The high column loading of $\mathrm{NO}_{2}$ in the northeastern part of China and the Pearl River Delta region was observed by various sensors (van der A et al., 2006) and was mainly due to the large consumption of fossil fuels by power plants, industries, and vehicles. Satellite detected higher signals of $\mathrm{O}_{3}$ and $\mathrm{CO}$ over the Southeast Asia region, especially over Burma, Northern Thailand, Vietnam and Southern China. Compared to observation, the model simulated stronger signals and overestimated around $20-50 \%$ over the most intense fire regions. In addition, the model predicted a more obvious transport pattern from the source region to over the Western Pacific, which is relatively weak from satellite. In other parts of the study domain, the model could relatively simulate well. The great uncertainty of biomass burning emission should be the major reason for the difficulty in modeling $\mathrm{CO}$ and $\mathrm{O}_{3}$ over source fire regions.

Figure 5 shows the monthly mean $\mathrm{AOD}, \mathrm{NO}_{2}, \mathrm{CO}$ and $\mathrm{O}_{3}$ plots from both satellite and modeled results. Generally, the model could well capture the spatial distribution of most species on the monthly basis. For AOD, the model slightly overestimated in the northern part of Southeast Asia, e.g. Burma, Laos, while underestimated in the southern part of Southeast Asia, mostly in Thailand. Correspondingly, the similar situation could be found in the monthly CO concentrations. In Burma, obvious overestimation was simulated. The model performance of $\mathrm{NO}_{2}$ was the best among the four species simulated above. The model performed very well in mainland China and simulated very consistent spatial distribution to the hot spots in Northern, Eastern China, and the Pearl River Delta region. There were some overestimations of $\mathrm{NO}_{2}$ over some limited regions in Southeast Asia. The relatively good model performance of $\mathrm{NO}_{2}$ concentrations was probably due to that its emission factor from biomass burning was relatively low compared to the anthropogenic sources. The simulation of $\mathrm{O}_{3}$ performed relatively well above $30^{\circ} \mathrm{N}$, however, it overestimated below it, especially in Southeast Asia and Southern China. The overestimation could reach about 10-20 ppbv. We suspected that the local biomass burning emission should be responsible for this.

In summary, the model could relatively well simulate the spatial distribution of typical pollutants emitted from biomass burning. In the next section, we will include with and without the biomass burning emission of Southeast Asia in the model to quantitatively assess the regional influences caused by biomass burning.

\subsection{Regional influences from biomass burning}

\subsubsection{Episodic impact from biomass burning}

In order to evaluate the impact of biomass burning on the source and the downstream regions, we performed a numerical scenario case without the biomass burning emissions over Southeast Asia in the model to compare to the base case with all the emission. Thus, the differences between the scenario case and the base case represented the contribution from biomass burning. Figure 6 illustrates the regional impact of biomass burning on the $\mathrm{CO}, \mathrm{O}_{3}$, and $\mathrm{PM}_{2.5}$ concentrations during the two episodes (27 March and 13 April) in 2006. The color contours denoted the differences between the base case and the scenario case, i.e. the gases and aerosol concentrations due to biomass burning. Red contoured lines denoted the percentage of the contribution from biomass burning. And the white arrows denoted the wind vectors in the 15th vertical layer at the altitude of $2.4 \mathrm{~km}$. This layer was chosen mainly because of significant long-range transport above it, which would be discussed in the next section.

During the first episode on 27 March, the largest impact from the biomass burning emissions covered areas of 10 to $25^{\circ} \mathrm{N}$ and 100 to $130^{\circ} \mathrm{E}$, extending from Southeast Asia to the West Pacific, which corresponded well to the satellite-observed spatial distribution in Fig. 4. As indicated by the red contoured lines, the potential benefits from the scenario without the total biomass burning emissions were 

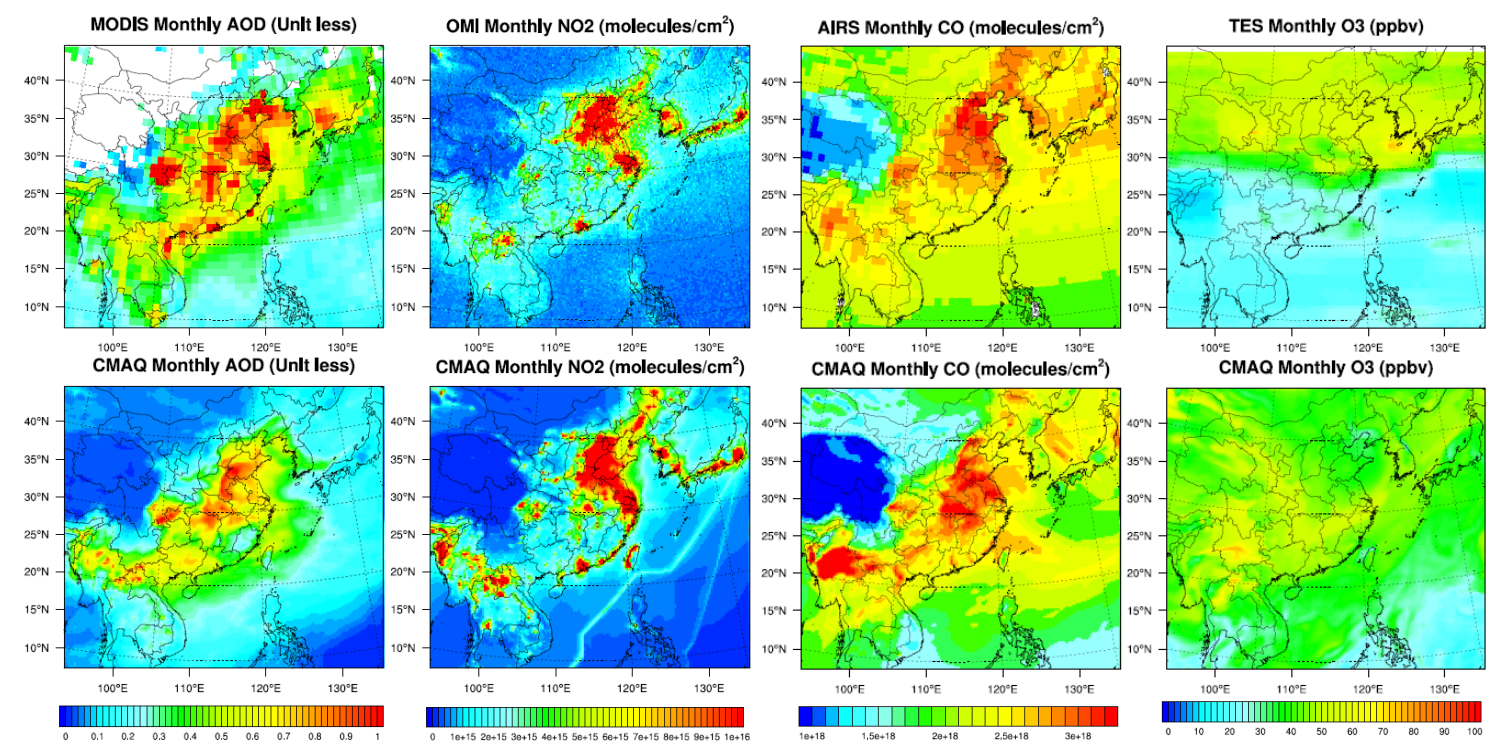

Fig. 5. The same as Fig. 4, but for monthly average comparison.

most prominent in the source region of Southeast Asia and over the transport pathways such as the nearby regions of Yunnan and Guangxi provinces in Southern China. In the source regions, biomass burning perturbed concentrations of $\mathrm{CO}, \mathrm{O}_{3}$, and $\mathrm{PM}_{2.5}$ by as much as $400 \mathrm{ppbv}, 20 \mathrm{ppbv}$ and $80 \mu \mathrm{g} \mathrm{m}^{-3}$, respectively. The percentages of the above three species attributed to biomass burning were in the ranges of 10 to $60 \%, 10$ to $20 \%$ and 30 to $70 \%$, respectively. It seemed that the contribution percentage of $\mathrm{O}_{3}$ from biomass burning was relatively small compared to $\mathrm{CO}$ and $\mathrm{PM}_{2.5}$, which was in agreement with previous results (Zhang et al., 2003).

The downwind areas were also strongly influenced by the long-range transport of biomass burning plumes. On 27 March, the impact spread over the southeastern parts of mainland China, including the Pearl River Delta region and Fujian province. The impact from biomass burning on these downwind regions amounted to about 160 to $360 \mathrm{ppbv}$ for $\mathrm{CO}, 8$ to $18 \mathrm{ppbv}$ for $\mathrm{O}_{3}$ and 8 to $64 \mu \mathrm{g} \mathrm{m}{ }^{-3}$ for $\mathrm{PM}_{2.5}$. The biomass burning outflows may also influence Taiwan and even the West Pacific. The transport impact could contribute about 20 to $50 \%$ on $\mathrm{CO}, 10$ to $30 \%$ on $\mathrm{O}_{3}$, and $70 \%$ on $\mathrm{PM}_{2.5}$, respectively.

Along the major export pathway of the plumes, biomass burning derived $\mathrm{CO}$ and $\mathrm{O}_{3}$ were spatially correlated with each other, probably indicating their common source. The transport pathways of biomass burning derived particles $\left(\mathrm{PM}_{2.5}\right)$ differed from $\mathrm{CO}$ and $\mathrm{O}_{3}$, which diffused quickly and covered relatively short distances. On 27 March, $\mathrm{PM}_{2.5}$ from biomass burning decreased from 40 to $80 \mu \mathrm{g} \mathrm{m}^{-3}$ over the continent to 8 to $20 \mu \mathrm{g} \mathrm{m}^{-3}$ over the ocean; thus, over $70 \%$ of the particles were scavenged during the transport. Compared to the gaseous pollutants, particles were more easily subject to scavenge through the wet/dry deposition.
As for the second episode on 13 April (Fig. 6), the impacts from biomass burning were not as widespread or intense as the first episode. The effects of biomass burning centered over the source region areas of Southeast Asia, Southern China, and the regions between Southern China and the South China Sea. Beyond the Pearl River Delta region, the impact became less significant, although weak influence of transported plume may still exist over oceanic areas as far as Japan (biomass burning derived $\mathrm{CO}$ and $\mathrm{O}_{3}<100$ ppbv and 6 ppbv, respectively with a negligible effect on $\mathrm{PM}_{2.5}$ ).

\subsubsection{Monthly impact from biomass burning}

Figure 7 shows the monthly average impact of biomass burning and wind patterns in March and April. In March, biomass burning in Southeast Asia mainly affected southern parts of East Asia. It contributed about 30 to $60 \%, 10$ to $20 \%$, and 20 to $70 \%$ of the total $\mathrm{CO}, \mathrm{O}_{3}$ and $\mathrm{PM}_{2.5}$ concentrations, respectively. The long-range transport had a significant impact over the Yunnan and Guangxi provinces in China and over the South China Sea around Hainan Island, with 140 to 180 ppbv CO derived from biomass burning. The transported $\mathrm{CO}$ extended over broad areas such as the Fujian, Jiangxi, and Hunan provinces in China and the South China Sea. The effect of biomass burning on these regions ranged from 40100 ppbv. As for $\mathrm{O}_{3}$, the area influenced was broader than that of $\mathrm{CO}$, with considerable biomass burning derived $\mathrm{O}_{3}$ concentration of about $8 \mathrm{ppbv}$ in the lower altitudes between $10^{\circ} \mathrm{N}$ and $15^{\circ} \mathrm{N}$. There was also a belt over the West Pacific with a biomass burning derived $\mathrm{O}_{3}$ concentration of 2 to 5 ppbv. The impact of biomass burning on $\mathrm{PM}_{2.5}$ was mainly confined to the source areas of Southeast Asia. The longrange transport of $\mathrm{PM}_{2.5}$ was restricted in Guangxi province, 

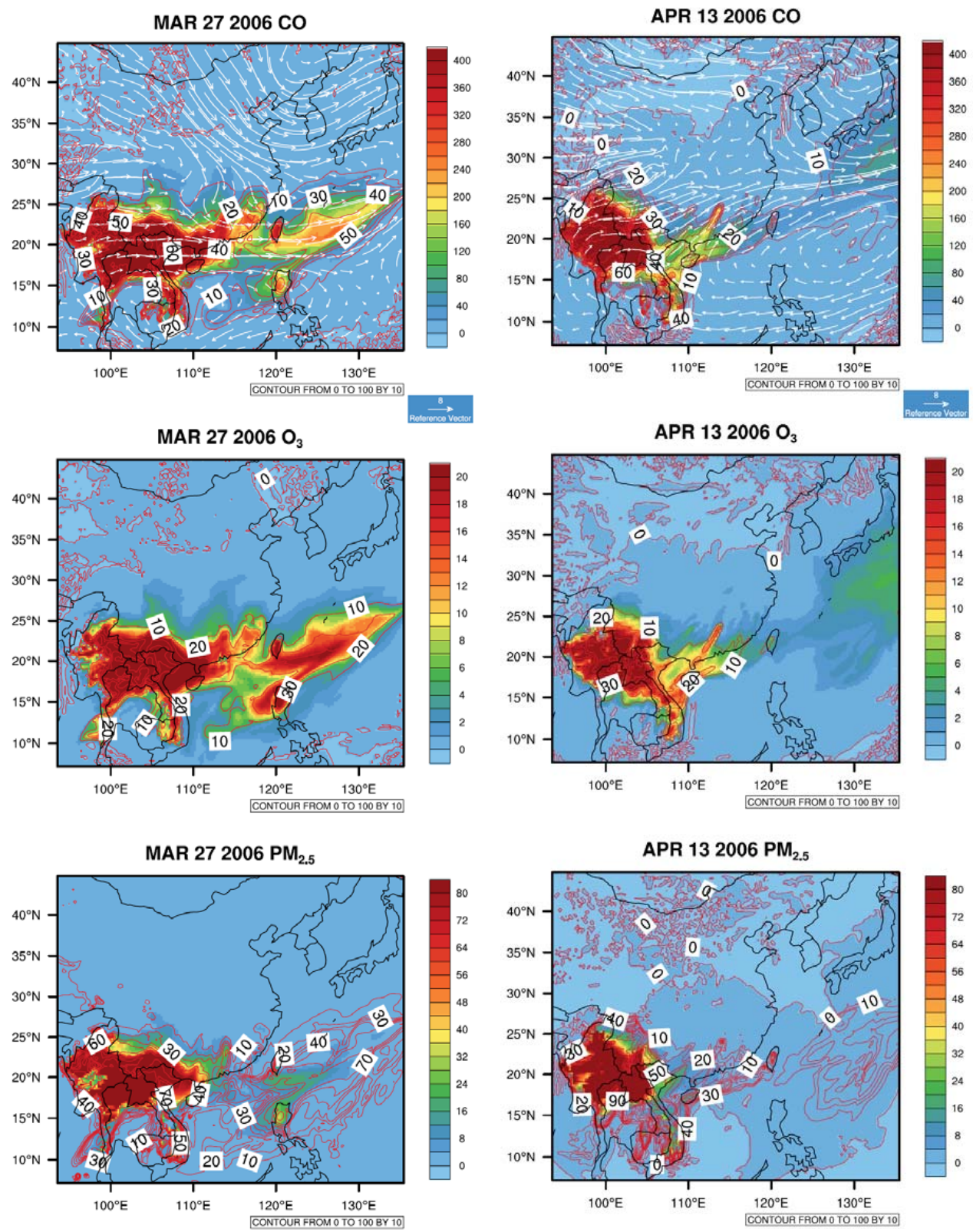

Fig. 6. Impact of biomass burning in Southeast Asia on 27 March and 13 April 2006. Color contour represents the concentrations for each species: the top panel shows $\mathrm{CO}$ (unit: ppbv) concentration, the middle panel shows $\mathrm{O}_{3}$ concentrations (unit: ppbv) and the bottom panel show $\mathrm{PM}_{2.5}$ concentrations (unit: $\mu \mathrm{g} \mathrm{m}^{-3}$ ). The red contour lines represent percentage contribution from biomass burning. The white arrows denote the wind vectors in the 15 th vertical layers at the altitude of $2.4 \mathrm{~km}$.

part of Guangdong and Yunnan provinces, and the South China Sea.

In April, the regional distribution pattern of biomass burning gases and aerosol slightly differed from March as shown in the figure. The impact from biomass burning in April evidently spread over broader regions and even reached the Yangtze River Delta region. For CO, its concentration from biomass burning that reached the Yangtze River Delta region was about 60 ppbv, and accounted for about $10 \%$ of the total concentration. Additionally, it was simulated that the transported CO concentrations over the South China Sea in April were higher than in March. In the source regions, we didn't find big differences between the two months. In April, ozone contributed by biomass burning plumes also covered a region broader than that in March. Over most of the Pearl River Delta region, the Guangxi province, and large areas of South China Sea, the $\mathrm{O}_{3}$ contribution by biomass burning plumes reached 9 to 11 ppbv. Additionally, the impact 




MAR $2006 \mathrm{O}_{3}$

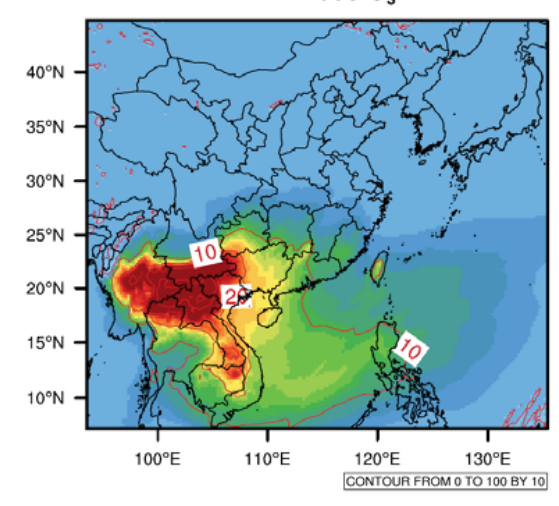

MAR $2006 \mathrm{PM}_{2.5}$

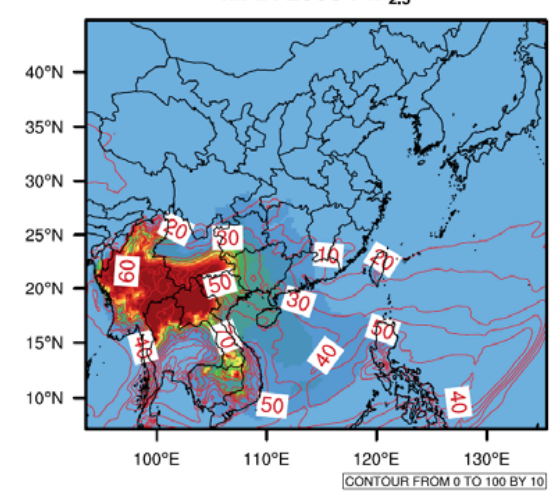

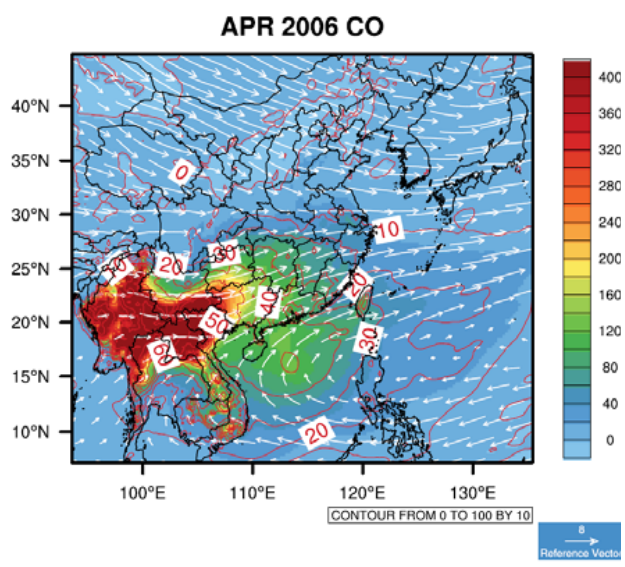


Fig. 7. Similar as Fig. 6 but monthly average impact during March and April in 2006.

of biomass burning on the $\mathrm{O}_{3}$ concentrations in parts of the Fujian, Jiangxi, and Hunan provinces reached about 8 ppbv, about 4 ppbv higher than in March. Another obvious difference was a high $\mathrm{O}_{3}$ concentration belt extending from the East China Sea to the regions below Japan. The fast dispersion of $\mathrm{O}_{3}$ was probably related to the prevailing wind pattern during this period. As for $\mathrm{PM}_{2.5}$, its transport was also more widespread and influenced major areas of southern China; the particulate contribution from biomass burning ranged from 10 to $30 \%$ in downwind areas.
The wind patterns were the main cause affecting the spatial distribution. As shown by the wind vectors in Fig. 7, the average wind fields in March at the latitudes of $17-25^{\circ} \mathrm{N}$ dominantly blew from west to east, which pushed the pollutants more eastward. Below $15^{\circ} \mathrm{N}$, wind blew from the east over the western Pacific and then circulated to higher latitudes which formed an anticyclone, that's why we observed that biomass burning impacted greatly over the South China Sea. In April, the wind fields changed and dominantly blew from low latitudes to the high latitudes which pushed the 


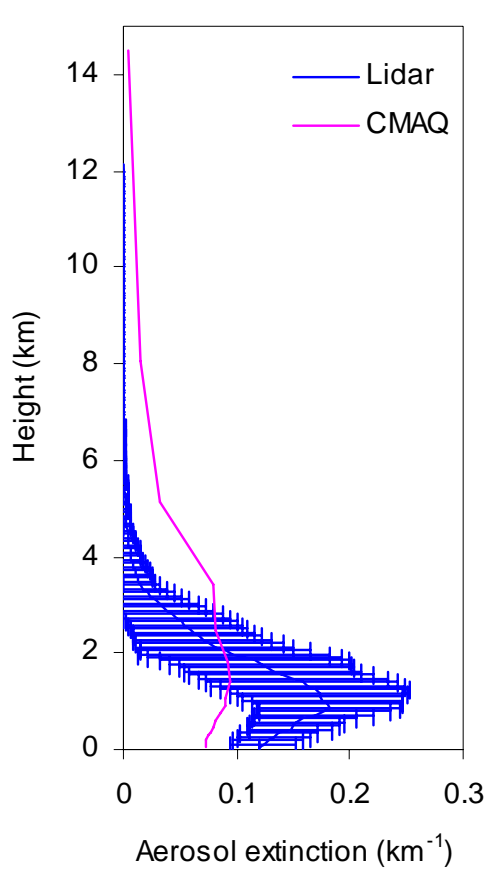

Fig. 8. Vertical distribution of aerosol extinction $\left(\mathrm{km}^{-1}\right)$ from both Lidar and CMAQ model at Phimai in Thailand $\left(15.19^{\circ} \mathrm{N}\right.$, $\left.102.56^{\circ} \mathrm{E}\right)$. One standard deviation of Lidar measured aerosol extinction was shown at interval height of every $75 \mathrm{~m}$.

emitted pollutants more northward and eastward, while the South China Sea was less impacted.

\subsection{Vertical distribution of biomass plumes}

Before we investigate the vertical transport pattern of biomass plumes, it is necessary to evaluate the model performance of vertical distribution. Figure 8 shows the comparison of vertical aerosol extinction between the model and a Micro-Pulse Lidar at Phimai in Thailand $\left(15.19^{\circ} \mathrm{N}\right.$, $102.56^{\circ} \mathrm{E}$ ). As shown in the figure, the model could generally captured the aerosol vertical distribution. Both lidar and model presented a decreasing trend of aerosol extinction coefficient from the ground to the high altitudes. However, there was underestimation below the PBL (i.e. around $2 \mathrm{~km}$ ), which could be due to underestimation of local anthropogenic emission near the ground. Some overestimation was observed at higher altitudes, which could be due to the problem of the allocation method of biomass burning emission. Generally, the vertical distribution of aerosol was reasonably well simulated, implying that the modeled vertical results could be further utilized.

Figures 9 and 10 show the simulated altitude-longitude cross-section of $\mathrm{CO}, \mathrm{O}_{3}$, and $\mathrm{PM}_{2.5}$ from biomass burning during the two episodes. The color contours and line contours denoted as the same meaning as in Fig. 7. The white arrows denoted the wind vectors at different vertical layers.
Two cross-sections at $15^{\circ} \mathrm{N}$ and $20^{\circ} \mathrm{N}$ were selected and compared, as this region was where the strongest biomass burning occurred. On 27 March at the cross section of $15^{\circ} \mathrm{N}$, we found that there was strong zonal gradient in concentrations. The blank areas with negligible emissions were over the open oceans. High $\mathrm{CO}$ and $\mathrm{O}_{3}$ concentrations in the boundary layers around $100^{\circ} \mathrm{E}, 105-110^{\circ} \mathrm{E}$, and $115-$ $122^{\circ} \mathrm{E}$ were noted. At $100^{\circ} \mathrm{E}$ and $105-110^{\circ} \mathrm{E}$, the vertical concentration gradient was very small or had an increasing trend from surface to high altitudes, which indicated that the pollutants were emitted from the lands in the source region. Driven by the strong air convection in the tropics, the local emissions lofted to high altitudes and then transported. This is why a plume layer existed at high altitudes of about 2 to $8 \mathrm{~km}$, which extended to around $130^{\circ} \mathrm{E}$ via the long range transport.

At around $115-122^{\circ} \mathrm{E}$, an obvious decreasing vertical gradient was observed from top to bottom, which suggests considerable deposition during the transport of biomass burning plumes. The percentage contributions of the transported plumes from biomass burning were 30 to $50 \%$ for $\mathrm{CO}, 20$ to $40 \%$ for $\mathrm{O}_{3}$ and over $70 \%$ for $\mathrm{PM}_{2.5}$ from the surface to altitude of about $10 \mathrm{~km}$. The cross-section of $20^{\circ} \mathrm{N}$ was quite different from that of $15^{\circ} \mathrm{N}$. The zonal gradient in concentrations is smaller, as this cross-section covered more land. Pollutants started to deposit at around $112^{\circ} \mathrm{E}$, as there was also a decreasing vertical gradient at this longitude. The longrange transport contributed 60 to $70 \%$ to $\mathrm{CO}, 20$ to $50 \%$ to $\mathrm{O}_{3}$, and $80 \%$ to $\mathrm{PM}_{2.5}$ from the surface to altitude of about $10 \mathrm{~km}$, respectively.

On 13 April, the transport of the biomass burning plumes was not as strong as on 27 March (Fig. 9), which was also consistent with our previous findings. On the cross-section of $15^{\circ} \mathrm{N}$, the main body of pollutants was located between $98^{\circ} \mathrm{E}$ and $110^{\circ} \mathrm{E}$. At the altitudes between $1 \mathrm{~km}$ and $5 \mathrm{~km}$, there also existed a plume layer with a short tail that transported to around $120^{\circ} \mathrm{E}$ for $\mathrm{CO}$ and $\mathrm{O}_{3}$. At the cross-section of $20^{\circ} \mathrm{N}$, the biomass burning emission intensified. The subsidence of pollutants was found at $105-115^{\circ} \mathrm{N}$, which was located at the junction of Vietnam and Guangxi province of China. The air pollutants could be depleted by various pathways during the subsidence.

As illustrated from the vertical structure of the biomass burning derived species, $\mathrm{CO}$ decreased from $400 \mathrm{ppbv}$ at the top to about 160 to $200 \mathrm{ppv}$, with a depletion percentage of 50 to $60 \% . \mathrm{O}_{3}$ decreased from $20 \mathrm{ppbv}$ to 8 to $10 \mathrm{ppbv}$, also with a depletion percentage of 50 to $60 \%$, while $\mathrm{PM}_{2.5}$ decreased from $80 \mu \mathrm{g} \mathrm{m}^{-3}$ to $16-24 \mu \mathrm{g} \mathrm{m}^{-3}$, with a high depletion percentage of 70 to $80 \%$. The high depletion percentage of particles during the subsidence probably was related with the interaction between particles and clouds. The contribution from biomass burning decreased with the decrease in altitude along the pathway of subsidence. As for $\mathrm{CO}$, the contribution was about $50 \%$ from the top to about $30 \%$ at the bottom; for $\mathrm{O}_{3}$, it was $60 \%$ to $20 \%$; for $\mathrm{PM}_{2.5}$, it was 

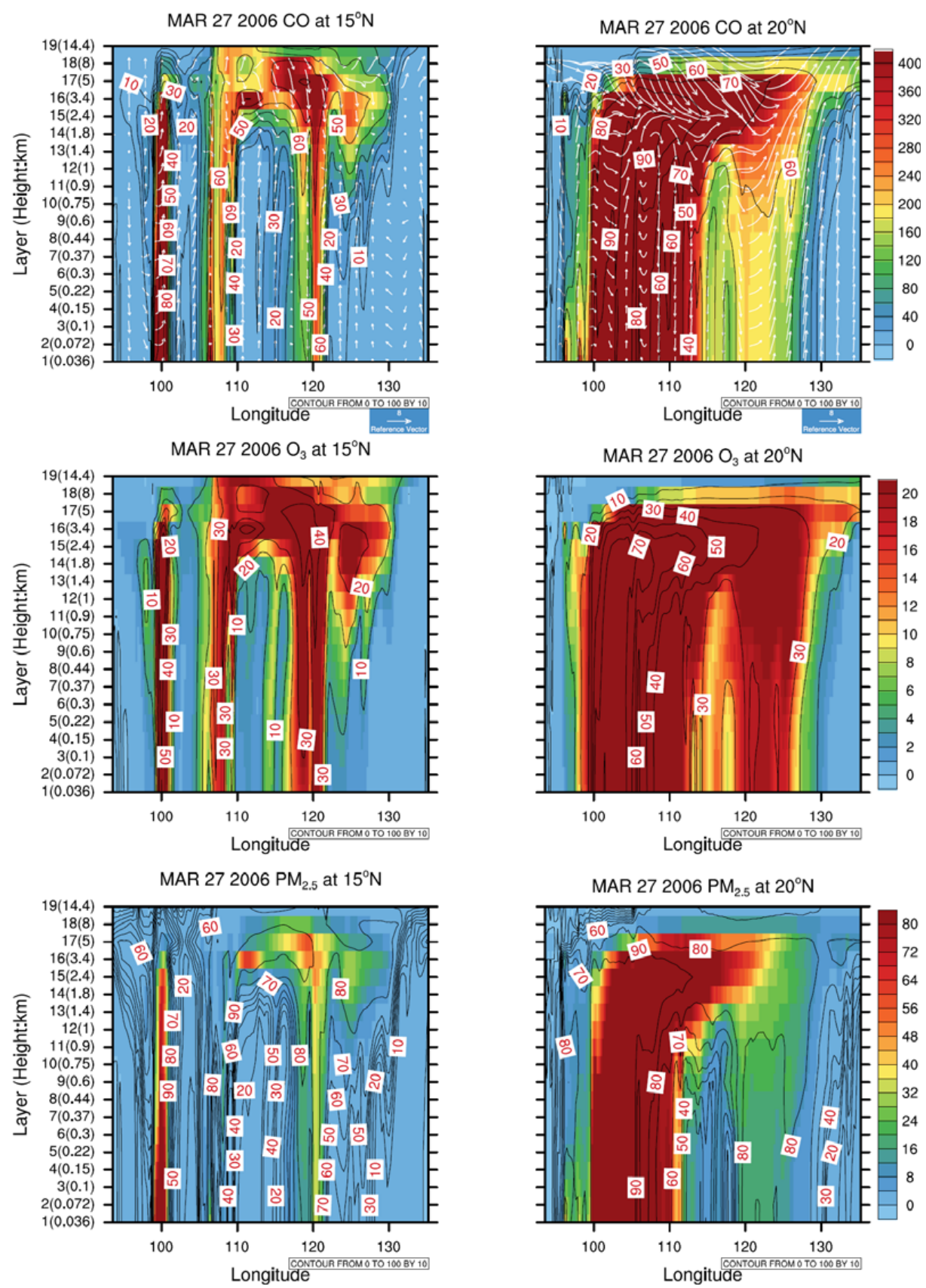

Fig. 9. Vertical transport and impact of biomass burning on 27 March 2006 at two cross sections of $15^{\circ} \mathrm{N}$ and $20^{\circ} \mathrm{N}$. Color contour represents the concentrations for each species at each layer. The top panel shows $\mathrm{CO}$ (unit: ppbv) concentration, the middle panel shows $\mathrm{O}_{3}$ concentrations (unit: ppbv) and the bottom panel show $\mathrm{PM}_{2.5}$ concentrations (unit: $\mu \mathrm{g} \mathrm{m}^{-3}$ ). The black contour lines represent percentage contribution from biomass burning at each layer. The white arrows denote the wind vectors in each layer.

$60 \%$ to $20 \%$. It seemed that the long-range transport of the biomass plumes exerted greater influence in the free troposphere than in the boundary layer.

\section{Conclusions}

In this paper, we evaluate the impact from Southeast Asia to East Asia during high biomass burning emissions periods in 2006. Through comparisons between the base case and scenario case without biomass burning emission, we find that biomass burning played a significant role in air 



Fig. 10. Similar as Fig. 7 but for the episode on 13 April 2006.

quality in both local and downwind areas. During the first episode on 27 March, the influence of biomass burning in the source region contributed to $\mathrm{CO}, \mathrm{O}_{3}$, and $\mathrm{PM}_{2.5}$ concentrations as high as $400 \mathrm{ppbv}, 20 \mathrm{ppbv}$, and $80 \mu \mathrm{g} \mathrm{m}^{-3}$, respectively. The reduction percentages of the concentrations on the above three species without biomass burning were in the range of 10 to $60 \%, 10$ to $20 \%$ and 30 to $70 \%$, respectively. Also, the impacts due to long-range transport could spread over the southeastern parts of mainland China, including the
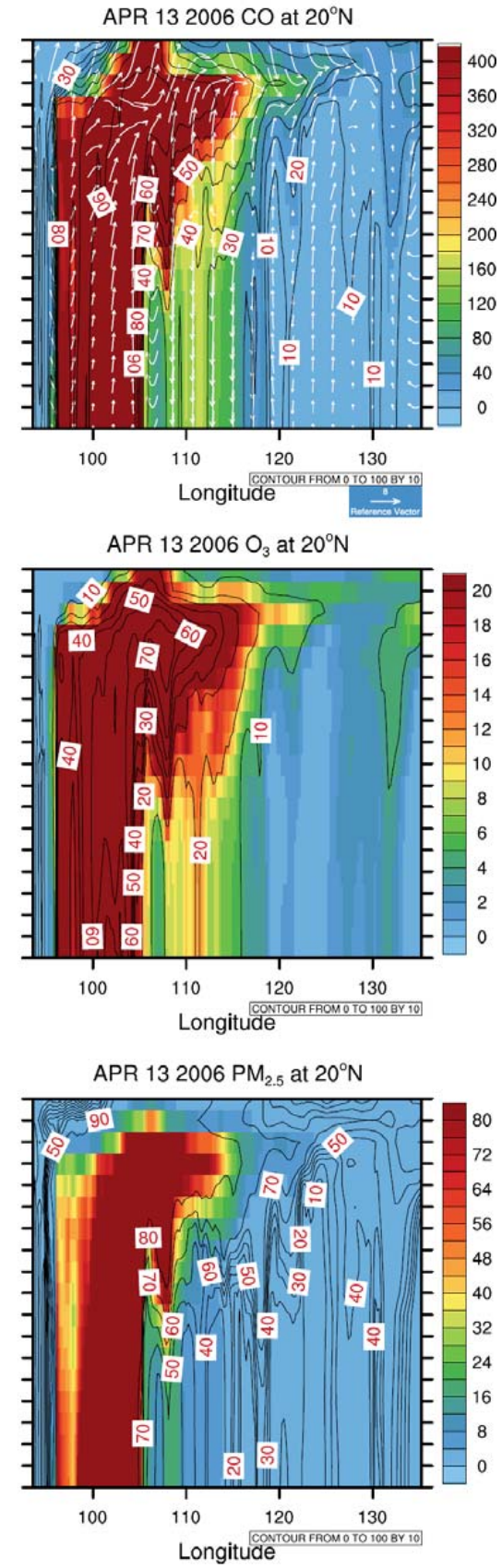

Pearl River Delta region and the Fujian province in China. The impact from biomass burning on this region could contribute about 160 to $360 \mathrm{ppbv} \mathrm{CO}, 8$ to $18 \mathrm{ppbv} \mathrm{O}_{3}$ and 8 to $64 \mu \mathrm{g} \mathrm{m}^{-3} \mathrm{PM}_{2.5}$, respectively; and the percentage impact could reach 20 to $50 \%$ on $\mathrm{CO}, 10$ to $30 \%$ on $\mathrm{O}_{3}$, and as high as $70 \%$ on $\mathrm{PM}_{2.5}$. During the second episode period on 13 April, the transport impact was a bit weaker for the southern areas of China than the first episode period, reflecting differences in both biomass burning intensity and wind pattern. 
The impact of biomass burning derived $\mathrm{CO}$ and $\mathrm{O}_{3}$ in Southeast Asia and southern China can reached about $100 \mathrm{ppbv}$ and 6 ppbv, respectively, while the impact on $\mathrm{PM}_{2.5}$ was not very significant.

In March, biomass burning in Southeast Asia had significant impact on southern parts of East Asia, especially the Yunnan and Guangxi provinces in China and over the South China Sea. Biomass burning contributed about 30 to $60 \%$, 10 to $20 \%$, and 20 to $70 \%$ to the total $\mathrm{CO}, \mathrm{O}_{3}$ and $\mathrm{PM}_{2.5}$ concentrations, respectively. In April, due to slightly different wind patterns, $\mathrm{CO}$ effects could reach the Yangtze River Delta with an impact of about $60 \mathrm{ppbv}$ (10 to 20\%). High concentrations of $\mathrm{O}_{3}$ extended farther in April. The $\mathrm{O}_{3}$ concentration reduction ranged from 9 to $11 \mathrm{ppbv}$ in the Pearl River Delta region, the Guangxi province in China, and large areas of the South China Sea. As for $\mathrm{PM}_{2.5}$, its transport was also more widespread and influenced major areas of southern China, with the particulate contribution from biomass burning ranged from 10 to $30 \%$.

Two cross-sections at $15^{\circ} \mathrm{N}$ and $20^{\circ} \mathrm{N}$ were selected to compare the vertical flux of biomass burning. In the source region (Southeast Asia), $\mathrm{CO}, \mathrm{O}_{3}$, and $\mathrm{PM}_{2.5}$ concentrations had a strong upward transport from surface to high altitudes. The transport became strong from 2 to $8 \mathrm{~km}$ in the free troposphere, and the pollutants were quickly transported eastward due to a strong western wind. The subsidence during the long-range transport contributed 60 to $70 \% \mathrm{CO}, 20$ to $50 \% \mathrm{O}_{3}$, and $80 \% \mathrm{PM}_{2.5}$, respectively, to surface in the downwind area. Though NASA's BASE-ASIA conducted this biomass burning measurement, it might be less active in biomass burning in 2006. This modeling study might provide constraints of lower limit. An additional study is underway for an active biomass burning year to obtain an upper limit.

\section{Appendix A}

\section{Statistical parameters for evaluating model performance}

Some general statistical parameters for model performance evaluation, i.e. MNB (Mean Normalized Bias), MNE (Mean Normalized Gross Error), MFB (Mean Fractional Bias) and MFE (Mean Fractional Gross Error). The calculations are shown in Eqs. (A1)-(A5) below, where $C_{\mathrm{m}}$ and $C_{\mathrm{o}}$ are the simulated model grid value and observational value at time and location $i$, respectively. And $N$ is the total number of samples by time and/or locations. However, as is shown in Eqs. (A1) and (A2), MNB and MNE can become extremely large when the observation data is quite low. For ozone, a cutoff of $40 \mathrm{ppb}$ or $60 \mathrm{ppb}$ is recommended and this will minimize the effect of normalization. MFB and MFE have the advantage of limiting the maximum model/observation bias and error. Benchmarks of MFB and MFE for $\mathrm{O}_{3}$ are $15 \%$ and $35 \%$, respectively. For $\mathrm{PM}_{2.5}$, they are $50 \%$ and $75 \%$, re- spectively (USEPA, 2007; Morris, 2005; Morris et al., 2006; Tesche et al., 2006).

$\mathrm{MNB}=\frac{1}{N} \sum_{i=1}^{N} \frac{C_{\mathrm{m}}-C_{\mathrm{o}}}{C_{\mathrm{o}}} \cdot 100 \%$

$\mathrm{MNE}=\frac{1}{N} \sum_{i=1}^{N} \frac{\left|C_{\mathrm{m}}-C_{\mathrm{o}}\right|}{C_{\mathrm{o}}} \cdot 100 \%$

$\mathrm{MFB}=\frac{1}{N} \sum_{i=1}^{N} \frac{C_{\mathrm{m}}-C_{\mathrm{o}}}{\left(C_{\mathrm{m}}+C_{\mathrm{o}}\right) / 2} \cdot 100 \%$

$\mathrm{MFE}=\frac{1}{N} \sum_{i=1}^{N} \frac{\left|C_{\mathrm{m}}-C_{\mathrm{o}}\right|}{\left(C_{\mathrm{m}}+C_{\mathrm{o}}\right) / 2} \cdot 100 \%$

The index of agreement (IOA) is calculated by Eq. (A5):

$\mathrm{IOA}=1-\frac{\sum_{i=1}^{N}\left(C_{\mathrm{m}}-C_{\mathrm{o}}\right)^{2}}{\sum_{i=1}^{N}\left(\left|C_{\mathrm{m}}-\overline{C_{\mathrm{o}}}\right|+\left|C_{\mathrm{o}}-\overline{C_{\mathrm{o}}}\right|\right)^{2}}$

The calculation of Factor 2 is shown in Eq. (A6):

$R=\frac{N_{[0.5,2]}}{N_{\mathrm{t}}}$

where $R$ is the percentage of the ratios between 0.5 and 2; $N[1 / 2,2]$ is the number of the ratios between 0.5 and 2; and $N_{\mathrm{t}}$ is the total number of comparison points.

\section{Appendix B}

\section{Method of calculating AOD from CMAQ model}

Aerosol Optical Depth (AOD) used in this study was estimated from the concentrations of aerosol chemical species generated from the CMAQ model. AOD was theoretically calculated by integrating the aerosol extinction coefficient $\left(\sigma_{\text {ext }}(z)\right)$ with respect to altitudes $(z)$, i.e.

$\mathrm{AOD}=\int \sigma_{\text {ext }}(z) \cdot \mathrm{d} z$

In the CMAQ model, total 19 layers from the surface to $14.4 \mathrm{~km}$ were integrated to represent the whole column AOD. We estimated the aerosol extinction coefficient by using an empirical approach known as reconstructed extinction. And this method was proposed by Malm et al. (1994), i.e.

$$
\begin{aligned}
& \sigma_{\text {ext }}\left(\mathrm{Mm}^{-1}\right)=3.0 \times f(\mathrm{RH}) \times\left\{\left[\left(\mathrm{NH}_{4}\right)_{2} \mathrm{SO}_{4}\right]+\left[\mathrm{NH}_{4} \mathrm{NO}_{3}\right]\right\} \\
& \quad+4.0 \times[\mathrm{SOAs}]+10.0 \times[\mathrm{BC}]+1.0 \\
& \quad \times[\text { fine }- \text { dust }]+0.6 \times[\text { coarse }- \text { dust }]
\end{aligned}
$$


The numbers in the front of each species were their specific mass extinction efficiency $\left(\mathrm{m}^{2} \mathrm{~g}^{-1}\right) . f(\mathrm{RH})$ denoted the hygroscopic growth factor, which determined the variability in $\sigma_{\text {ext }}$ caused by the relative humidity. In the estimation, only sulfate and nitrate were considered hygroscopic. $f(\mathrm{RH})$ was obtained from a table of corrections with entries at onepercent intervals. The methodology for the corrections was given in Malm et al. (1994).

Acknowledgements. We thank Edward J. Hyer for providing FLAMBE biomass burning emission data. We thank NASA GSFC on funding support (grant no.: NNX09AG75G). Data products from SMART-COMMIT and Deep Blue groups of NASA GSFC are funded by the NASA Radiation Sciences Program, managed by Hal Maring. Hong Kong data was obtained from Hong Kong Environmental Protection Department.

Edited by: F. Yu

\section{References}

Air Sciences, Inc.: 2002 Fire Emission Inventory for the WRAP Region - Phase II, Preared for the Western Governors Association/WRAP by Air Sciences, Inc., Denver, CO, 2005.

Allen, D. J., Kasibhatla, P., Thompson, A. M., Rood, R. B., Doddridge, B. G., Pickering, K. E., Hudson, R. D., and Lin, S. J.: Transport-induced interannual variability of carbon monoxide determined using a chemistry and transport model, J. Geophys. Res., 101, 28655-28669, 1996a.

Allen, D. J., Rood, R. B., Thompson, A. M., and Hudson, R. D.: Three-dimensional radon 222 calculations using assimilated meteorological data and a convective mixing algorithm, J. Geophys. Res., 101, 6871-6881, 1996b.

Andreae, M. O. and Merlet, P.: Emission of trace gases and aerosols from biomass burning, Global Biogeochem. Cy., 15, 955-966, 2001.

Bucsela, E., Celarier, E. A., Wenig, M. O., Gleason, J. F., Veefkind, J. P., Boersma, K. F., and Brinksma, E. J.: Algorithm for $\mathrm{NO}_{2}$ vertical column retrieval from the Ozone Monitoring Instrument, IEEE Trans. Geosci. Remote Sens., 44, 1245-1258, 2006.

Byun, D. W. and Ching J. K. S.: Science algorithm of the EPA Models-3 Community Multiscale Air Quality(CMAQ) Modeling System, EPA/600/R-699/030 pp, United States Environmental Protection Agency, Washington, DC, 1999.

Byun, D. and Schere, K. L.: Review of the governing equations, computational algorithms, and other components of the models3 Community Multiscale Air Quality (CMAQ) modeling system, Appl. Mech. Rev., 59, 51-77, 2006.

Carmichael, G. R., Sakurai, T., Streets, D., Hozumi, Y., Ueda, H., Park, S.U., Fung, C., Han, Z., Kajino, M., Engardt, M., Bennet, C., Hayami, H., Sartelet, K., Holloway, T., Wang, Z., Kannari, A., Fu, J. S., Matsuda, K., Thongboonchoo, N., and Amann, M.: MICS-Asia II: The Model Intercomparison Study for Asia Phase II: Methodology and Overview of Findings, Atmos. Environ., 42, 3468-3490, 2008.

Chand, D., Guyon, P., Artaxo, P., Schmid, O., Frank, G. P., Rizzo, L. V., Mayol-Bracero, O. L., Gatti, L. V., and Andreae, M. O.: Optical and physical properties of aerosols in the boundary layer and free troposphere over the Amazon Basin during the biomass burning season, Atmos. Chem. Phys., 6, 2911-2925, doi:10.5194/acp-6-2911-2006, 2006.

Choi, S. D. and Chang, Y. S.: Carbon monoxide monitoring in Northeast Asia using MOPITT: Effects of biomass burning and regional pollution in April 2000, Atmos. Environ., 40, 686-697, 2006.

Chuang, M. T., Fu, J. S., Jang, C. J., Chan, C. C., Ni, P. C., and Lee, C. T.: Simulation of A Long-range Transport Aerosols from the Asian Continent to Taiwan by a Southward Asian High-pressure System, Sci. Total Environ., 406, 168-179, 2008.

Davidi, A., Koren, I., and Remer, L.: Direct measurements of the effect of biomass burning over the Amazon on the atmospheric temperature profile, Atmos. Chem. Phys., 9, 8211-8221, doi:10.5194/acp-9-8211-2009, 2009.

Deng, X. J., Tie, X. X., Zhou, X. J., Wo, D., Zhong, L. J., Tan, H. B., Li, F., Huang, X. Y., Bi, X. Y., and Deng, T.: Effects of Southeast Asia biomass burning on aerosols and ozone concentrations over the Pearl River Delta (PRD) region, Atmos. Environ., 42, 84938501, 2008.

Dickerson, R. R. and Delany, A. C.: Modification of a commercial gas filter correlation $\mathrm{CO}$ detector for enhanced sensitivity, J. Atmos. Oceanic Technol., 5, 424-431, 1988.

Du, Y.: New Consolidation of Emission and Processing for Air Quality Modeling Assessment in Asia, Master Thesis, University of Tennessee, Knoxville, 2008.

Freitas, S. R., Longo, K. M., and Andreae, M. O.: Impact of including the plume rise of vegetation fires in numerical simulations of associated atmospheric pollutants, Geophys. Res. Lett., 33, L17808, doi:10.1029/2006GL026608, 2006.

Fu, J. S., Jang, C. C., Streets, D. G., Li, Z., Kwok, R., Park, R., and Han, Z.: MICS-Asia II: Evaluating Gaseous Pollutants in East Asia Using An Advanced Modeling System: Models-3/CMAQ System, Atmos. Environ., 42, 3571-3583, 2008.

Fu, J. S., Yeh, F. L., Carey, C. J., Chen, R. J., and Chuang, M. T.: Air Quality Modelling - An Investigation of The Merits of CMAQ In The Analysis of Trans-boundary Air Pollution From Continents to Small Islands, International Journal of Environmental Technology and Management, 10, 22-31, 2009a.

Fu, J. S., Streets, D. G., Jang, C. J., Hao, J., He, K., Wang, L., and Zhang, Q.: Modeling Regional/Urban Ozone and Particulate Matter in Beijing, China, Journal of Air and Waste Management 59, 37-44, 2009b.

Gustafsson, O., Krusa, M., Zencak, Z., Sheesley, R. J., Granat, L., Engstrom, E., Praveen, P. S., Rao, P. S. P., Leck, C., and Rodhe, H.: Brown Clouds over South Asia: Biomass or Fossil Fuel Combustion?, Science, 323, 5913, 495-498, 2009.

Guyon, P., Frank, G. P., Welling, M., Chand, D., Artaxo, P., Rizzo, L., Nishioka, G., Kolle, O., Fritsch, H., Silva Dias, M. A. F, Gatti, L. V., Cordova, A. M., and Andreae, M. O.: Airborne measurements of trace gas and aerosol particle emissions from biomass burning in Amazonia, Atmos. Chem. Phys., 5, 29893002, doi:10.5194/acp-5-2989-2005, 2005.

Haywood, J. M., Pelon, J., Formenti, P., Bharmal, N., Brooks, M., Capes, G., Chazette, P., Chou, C., Christopher, S., Coe, H., Cuesta, J., Derimian, Y., Desboeufs, K., Greed, G., Harrison, M., Heese, B., Highwood, E. J., Johnson, B., Mallet, M., Marticorena, B., Marsham, J., Milton, S., Myhre, G., Osborne, S. R., Parker, D. J., Rajot, J. L., Schulz, M., Slingo, A., Tanre, D., and Tulet, P.: Overview of the Dust and Biomass-burning 
Experiment and African Monsoon Multidisciplinary Analysis Special Observing Period-0, J. Geophys. Res., 113, D00C17, doi:10.1029/2008JD010077, 2008.

Huang, K., Zhuang, G., Lin, Y., Li, J., Sun, Y., Zhang, W., and Fu, J. S.: Relation between optical and chemical properties of dust aerosol over Beijing, China, J. Geophys. Res., 115, D00K16, doi:10.1029/2009JD013212, 2010.

Hyer, E. J., Allen, D. J., and Kasischke, E. S.: Examining injection properties of boreal forest fires using surface and satellite measurements of CO transport, J. Geophys. Res., 112, D18307, doi:10.1029/2006JD008232, 2007.

IPCC: The Physical Science Basis. Contribution of Working Group I to the Fourth Assessment Report of the Intergovernmental Panel on Climate Change, edited by: Solomon, S., Qin, D., Manning, M., Chen, Z., Marquis, M., Averyt, K. B., Tignor, M., and Miller, H. L., Cambridge University Press, Cambridge, United Kingdom and New York, NY, USA, 2007.

Kim, J., Yoon, S. C., Jefferson, A., and Kim, S. W.: Aerosol hygroscopic properties during Asian dust, pollution, and biomass burning episodes at Gosan, Korea in April 2001, Atmos. Environ., 40, 1550-1560, 2006.

Kim, S.-W., Chazette, P., Dulac, F., Sanak, J., Johnson, B., and Yoon, S.-C.: Vertical structure of aerosols and water vapor over West Africa during the African monsoon dry season, Atmos. Chem. Phys., 9, 8017-8038, doi:10.5194/acp-9-8017-2009, 2009.

Krotkov, N. A., McClure, B., Dickerson, R. R., Carn, S. A., Li, C., Bhartia, P. K., Yang, K., Krueger, A. J., Li, Z. Q., Levelt, P. F., Chen, H. B., Wang, P. C., and Lu, D. R.: Validation of SO2 retrievals from the Ozone Monitoring Instrument over NE China, J. Geophys. Res., 113, D16S40, doi:10.1029/2007JD008818, 2008.

Kwok, R. H. F., Fung, J. C. H., Lau, A. K. H., and Fu, J. S.: Numerical study on seasonal variations of gaseous pollutants and particulate matters in Hong Kong and Pearl River Delta Region, J. Geophys. Res., 115, D16308, doi:10.1029/2009JD012809, 2010.

Leung, F.-Y. T., Logan, J. A., Park, R., Hyer, E. J., Kasischke, E. S., Streets, D. G., and Yurganov, L.: Impacts of enhanced biomass burning in the boreal forests in 1998 on tropospheric chemistry and the sensitivity of model results to the injection height of emissions, J. Geophys. Res., 112, D10313, doi:10.1029/2006JD008132, 2007.

Levelt, P. F., Van den Oord, G. H. J., Dobber, M. R., Malkki, A., Visser, H., de Vries, J., Stammes, P., Lundell, J. O. V., and Saari, H.: The Ozone Monitoring Instrument, IEEE Trans. Geosci. Remote Sens., 44, 1093-1101, 2006.

Li, C., Krotkov, N. A., Dickerson, R. R., Li, Z. Q., Yang, K., and Chin, M.: Transport and evolution of a pollution plume from northern China: A satellite-based case study, J. Geophys. Res., 115, D00K03, doi:10.1029/2009JD012245, 2010a.

Li, C., Tsay, S. C., Fu, J. S., Dickerson, R., Ji, Q., Bell, S., Gao, Y., Zhang, W., Huang, J., Li, Z., and Chen, H.: Anthropogenic Air Pollution Observed near Dust Source Regions in Northwestern China during Springtime 2008, J. Geophys. Res., 115, D00K22, doi:10.1029/2009JD013659, 2010b.

Li, C., Zhang, Q., Krotkov, N. A., Streets, D. G., He, K. B., Tsay, S. C., and Gleason, J. F.: Recent large reduction in sulfur dioxide emissions from Chinese power plants observed by the Ozone Monitoring Instrument, Geophys. Res. Lett., 37, L08807,
doi:10.1029/2010GL042594, 2010c.

Lin, C.-Y., Hsu, H.-m., Lee, Y. H., Kuo, C. H., Sheng, Y.-F., and Chu, D. A.: A new transport mechanism of biomass burning from Indochina as identified by modeling studies, Atmos. Chem. Phys., 9, 7901-7911, doi:10.5194/acp-9-7901-2009, 2009.

Liu, H. Y., Chang, W. L., Oltmans, S. J., Chan, L. Y., and Harris, J. M.: On springtime high ozone events in the lower troposphere from Southeast Asian biomass burning, Atmos. Environ., 33, 2403-2410, 1999.

Malm, W. C., Sisler, J. F., Huffman, D., Eldred, R. A., and Cahill, T. A.: Spatial and Seasonal Trends in Particle Concentration and Optical Extinction in the United-States, J. Geophys. Res.Atmos., 99, 1347-1370, 1994.

Mari, C. H., Cailley, G., Corre, L., Saunois, M., Attié, J. L., Thouret, V., and Stohl, A.: Tracing biomass burning plumes from the Southern Hemisphere during the AMMA 2006 wet season experiment, Atmos. Chem. Phys., 8, 3951-3961, doi:10.5194/acp-8-3951-2008, 2008.

Martin, R. V.: Satellite remote sensing of surface air quality, Atmos. Environ., 42, 7823-7843, 2008.

Morris, R. and Koo, B.: Application of Multiple Models to Simulation Fine Particulate in the Southeastern US, National RPO Modeling Meeting, Denver, CO, 2005.

Morris, R. E., Koo, B., Guenther, A., Yarwood, G., McNally, D., Tesche, T. W., Tonnesen, G., Boylan, J., and Brewer, P.: Model sensitivity evaluation for organic carbon using two multipollutant air quality models that simulate regional haze in the southeastern United States, Atmos. Environ., 40, 4960-4972, 2006.

Nam, J., Wang, Y., Luo, C., and Chu, D. A.: Trans-Pacific transport of Asian dust and CO: accumulation of biomass burning $\mathrm{CO}$ in the subtropics and dipole structure of transport, Atmos. Chem. Phys., 10, 3297-3308, doi:10.5194/acp-10-3297-2010, 2010.

Patra, P. K., Ishizawa, M., Maksyutov, S., Nakazawa, T., and Inoue, G.: Role of biomass burning and climate anomalies for land-atmosphere carbon fluxes based on inverse modeling of atmospheric $\mathrm{CO}_{2}$, Global Biogeochem. Cy., 19, GB3005, doi:10.1029/2004GB002258, 2005.

Potter, C., Genovese, V. B., Klooster, S., Bobo, M., and Torregrosa, A.: Biomass burning losses of carbon estimated from ecosystem modeling and satellite data analysis for the Brazilian Amazon region, Atmos. Environ., 35, 1773-1781, 2001.

Reid, J. S., Koppmann, R., Eck, T. F., and Eleuterio, D. P.: A review of biomass burning emissions part II: intensive physical properties of biomass burning particles, Atmos. Chem. Phys., 5, 799825, doi:10.5194/acp-5-799-2005, 2005.

Reid, J. S., Hyer, E. J., Prins, E. M., Westphal, D. L., Jianglong, Z., Jun, W., Christopher, S. A., Curtis, C. A., Schmidt, C. C., Eleuterio, D. P., Richardson, K. A., and Hoffman, J. P.: Global Monitoring and Forecasting of Biomass-Burning Smoke: Description of and Lessons From the Fire Locating and Modeling of Burning Emissions (FLAMBE) Program, Selected Topics in Applied Earth Observations and Remote Sensing, IEEE Journal of Selected Topics in Applied Earth Observations and Remote Sensing, 2, 144-162, 2009.

Remer, L. A., Kaufman, Y. J., Tanre, D., Mattoo, S., Chu, D. A., Martins, J. V., Li, R. R., Ichoku, C., Levy, R. C., Kleidman, R. G., Eck, T. F., Vermote, E., and Holben, B. N.: The MODIS aerosol algorithm, products, and validation, J. Atmos. Sci., 62, 
947-973, 2005.

Richter, A., Burrows, J. P., Nuss, H., Granier, C., and Niemeier, U.: Increase in tropospheric nitrogen dioxide over China observed from space, Nature, 437, 7055, 129-132, 2005.

Rissler, J., Vestin, A., Swietlicki, E., Fisch, G., Zhou, J., Artaxo, P., and Andreae, M. O.: Size distribution and hygroscopic properties of aerosol particles from dry-season biomass burning in Amazonia, Atmos. Chem. Phys., 6, 471-491, doi:10.5194/acp6-471-2006, 2006.

Sherwood, S.: A microphysical connection among biomass burning, cumulus clouds, and stratospheric moisture, Science, 295, 5558, 1272-1275, 2002.

Streets, D. G., Bond, T. C., Lee, T., and Jang, C.: On the future of carbonaceous aerosol emissions, J. Geophys. Res., 109, D24212, doi:10.1029/2004JD004902, 2004.

Streets, D. G., Fu, J. S., Jang, C., Hao, J., He, K., Tang, X., Zhang, Y., Li, Z., Zhang, Q., Wang, L., Wang, B., and Yu, C.: Air quality during the 2008 Beijing Olympic games, Atmos. Environ., 41, 480-492, 2007.

Swap, R. J., Annegarn, H. J., Suttles, J. T., King, M. D., Platnick, S., Privette, J. L., and Scholes, R. J.: Africa burning: A thematic analysis of the Southern African Regional Science Initiative (SAFARI 2000), J. Geophys. Res., 108, 8465, doi:10.1029/2003JD003747, 2003.

Tang, Y. H., Carmichael, G. R., Woo, J. H., Thongboonchoo, N., Kurata, G., Uno, I., Streets, D. G., Blake, D. R., Weber, R. J., Talbot, R. W., Kondo, Y., Singh, H. B., and Wang, T.: Influences of biomass burning during the Transport and Chemical Evolution Over the Pacific (TRACE-P) experiment identified by the regional chemical transport model, J. Geophys. Res., 108, 8824, doi:10.1029/2002JD003110, 2003.

Tanŕe, D., Kaufman, Y. J., Herman, M., and Mattoo, S.: Remote sensing of aerosol properties over oceans using the MODIS/EOS spectral radiances, J. Geophys. Res., 102, 1697116988, doi:10.1029/96JD03437, 1997.

Tesche, T. W., Morris, R., Tonnesen, G., McNally, D., Boylan, J., and Brewer, P.: CMAQ/CAMx annual 2002 performance evaluation over the eastern US, Atmos. Environ., 40, 4906-4919, 2006.

Thompson, A. M., Witte, J. C., Hudson, R. D., Guo, H., Herman, J. R., and Fujiwara, M.: Tropical Tropospheric Ozone and Biomass Burning, Science, 291, 5511, 2128-2132, 2001.

USEPA: Guidance on the Use of Models and Other Analyses for Demonstrating Attainment of Air Quality Goals for Ozone, $\mathrm{PM}_{2.5}$ and Regional Haze, EPA-454/B-07e002. USEPA, 2007.

van $\operatorname{der}$ A, R. J., Peters, D. H. M. U., Eskes, H., Boersma, K. F., Van Roozendael, M., De Smedt, I., and Kelder, H. M.: Detection of the trend and seasonal variation in tropospheric $\mathrm{NO}_{2}$ over China, J. Geophys. Res., 111, D12317, doi:10.1029/2005JD006594, 2006. van der Werf, G. R., Randerson, J. T., Giglio, L., Collatz, G. J., Kasibhatla, P. S., and Arellano Jr., A. F.: Interannual variability in global biomass burning emissions from 1997 to 2004, Atmos. Chem. Phys., 6, 3423-3441, doi:10.5194/acp-6-3423-2006, 2006.

Wang, S. H., Lin, N. H., Chou, M. D., and Woo, J. H.: Estimate of radiative forcing of Asian biomass-burning aerosols during the period of TRACE-P, J. Geophys. Res., 112, D10222, doi:10.1029/2006JD007564, 2007.

Wang, L., Hao, J., He, K., Wang, S., Li, J., Zhang, Q., Streets, D., Fu, J. S., Jang, C. J., Takekawa, H., and Chatani, S.: Modeling Study on PM10 Pollution in Beijing: Regional Contributions and Control Implications, J. Air Waste Manage., 58, 1057-1069, 2008.

Wang, L., Carey, J., Zhang, Y., Wang, K., Zhang, Q., Streets, D., Fu, J., Lei, Y., Schreifels, J., He, K., Hao, J., Lam, Y. F., Lin, J., Meskhidze, N., Voorhees, S., Evarts, D., and Phillips, S.: Assessment of air quality bene?ts from national air pollution control policies in China. Part I: Background, emission scenarios and evaluation of meteorological predictions, Atmos. Environ., 44, 3442-3448, 2010.

Winkler, H., Formenti, P., Esterhuyse, D. J., Swap, R. J., Helas, G., Annegarn, H. J., and Andreae, M. O.: Evidence for largescale transport of biomass burning aerosols from sunphotometry at a remote South African site, Atmos. Environ., 42, 5569-5578, 2008.

Xu, J., Zhang, Y., Fu, J. S., and Wang, W.: Process Analysis of Typical Ozone Episode in Summer over Beijing Area, Sci. Total Environ., 399, 147-157, 2008.

Zhang, Y.: Online-coupled meteorology and chemistry models: history, current status, and outlook, Atmos. Chem. Phys., 8, 2895 2932, doi:10.5194/acp-8-2895-2008, 2008.

Zhang, M. G., Uno, I., Carmichael, G. R., Akimoto, H., Wang, Z. F., Tang, Y. H., Woo, J. H., Streets, D. G., Sachse, G. W., Avery, M. A., Weber, R. J., and Talbot, R. W.: Large-scale structure of trace gas and aerosol distributions over the western $\mathrm{Pa}$ cific Ocean during the Transport and Chemical Evolution Over the Pacific (TRACE-P) experiment, J. Geophys. Res., 108, 8820, doi:10.1029/2002JD002946, 2003.

Zhang, Q., Streets, D. G., Carmichael, G. R., He, K. B., Huo, H., Kannari, A., Klimont, Z., Park, I. S., Reddy, S., Fu, J. S., Chen, D., Duan, L., Lei, Y., Wang, L. T., and Yao, Z. L.: Asian emissions in 2006 for the NASA INTEX-B mission, Atmos. Chem. Phys., 9, 5131-5153, doi:10.5194/acp-9-5131-2009, 2009.

Zhang, W., Zhuang, G., Huang, K., Li, J., Zhang, R., Wang, Q., Sun, Y., Fu, J. S., Chen, Y., Xu, D., and Wang, W.: Mixing and transformation of Asian dust with pollution in the two dust storms over the northern China in 2006, Atmos. Environ., 44, 3394-3403, 2010. 